Review Article

Andrzej Borawski*

\title{
Conventional and unconventional materials used in the production of brake pads - review
}

https://doi.org/10.1515/secm-2020-0041

Received May 08, 2020; accepted Aug 31, 2020

\begin{abstract}
Brakes are one of the most important components of vehicle. The brake system must be reliable and display unchanging action throughout its use, as it guards the health and life of many people. Properly matched friction pair, a disc and brake pad (in disc brakes), have a great impact on these factors. In most cases, the disc is made of grey cast iron. The brake pads are far more complex components. New technologies make it possible to develop materials with various compositions and different proportions, and connect them permanently in fully controllable processes. This elaboration shows that all these factors have a greater or lesser impact on the coefficient of friction, resistance to friction wear and high temperature, and brake pad's operating life. This review collects the most important, the most interesting, and the most unconventional materials used in production of brake pads, and characterizes their impact on the tribological properties of pads.
\end{abstract}

Keywords: brake pads, tribological properties, friction material, brake pad design, tribochemistry

\section{Introduction}

The significance of the braking system in any vehicles is enormous. Its main function is reducing the speed of the moving vehicle or stopping it completely. The braking system must therefore be reliable, and the efficiency of brakes must remain constant throughout their lifespan and in changing atmospheric conditions $[1,2]$. The wellbeing and life of the vehicle's passengers rests upon it, but also of other, accidental participants of road and pedestrian traffic [3].

`Corresponding Author: Andrzej Borawski: Bialystok University of Technology, Faculty of Mechanical Engineering, Wiejska 45C, 15-351 Bialystok, Poland; Email: a.borawski@pb.edu.pl

๖ Open Access. () 2020 A. Borawski, published by De Gruyter. (Cc) BY License
Most vehicles manufactured today use disc brakes (Figure 1). The main element of this type of design is the disc, spinning alongside the road wheel, and the brake pad, connected with the hub via a calliper [4]. As the pad is pressed against the disc, friction occurs which transforms kinetic energy into heat. The energy, in the form of heat, is then released into the atmosphere $[5,6]$. This is a necessity, as excess heat may damage the suspension elements, which are made from plastics, or even tires [7].

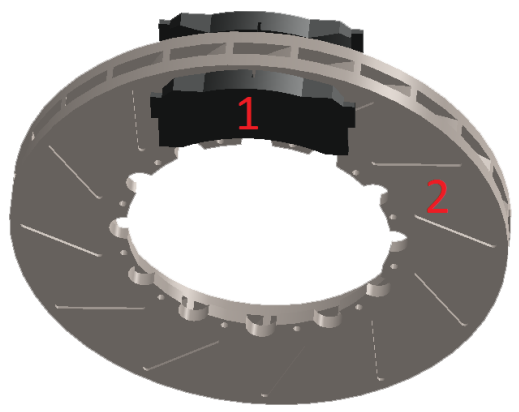

Figure 1: Disc brake friction pair: 1 - brake pads and 2 - corresponding brake disc

The friction force largely depends on the materials used in the production of the friction pair [8]. Brake discs are largely made from grey cast iron, as it is characterised by good thermal conductivity and anti-vibration capacity [9]. Newest disc solutions, especially in sports cars, utilise composite materials based on ceramics [10].

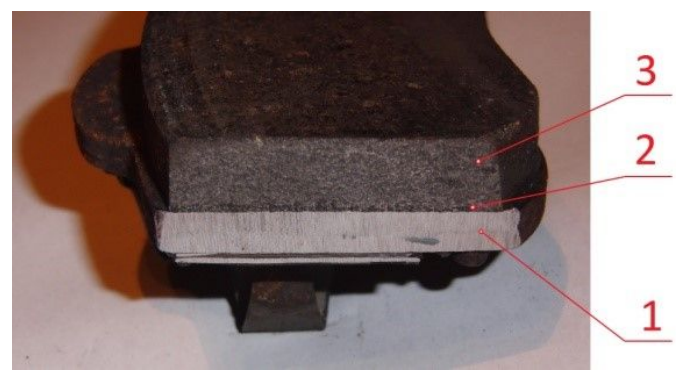

Figure 2: Key brake pad components: 1- back plate, 2- underlayer, 3 friction material

This work is licensed under the Creative Commons Attribution 4.0 
Matters are different for brake pads. Their structure is far more complicated. Brake pads have specific layers (Fig ure 2), the most important of which is the friction layer - layer that we brake during the normal operation of the brake pad [11]. It is usually 6 to $9 \mathrm{~mm}$ thick. Its composition differs significantly and is adjusted to specific purposes. Beneath the friction material is the so-called underlayer. It is $1-4 \mathrm{~mm}$ thick and acts as an adhesive holding the friction material. The underlayer is placed on a thin (usually under $1 \mathrm{~mm}$ ) layer of a base coat which improves its grip to the "spin" of the brake pad, the back plate. The base coat also ensures a certain level of thermal isolation. This is to prevent excess heat from reaching the braking fluid. The back plate provides the necessary stiffness of the brake pad, and allows it to move along the guide of the calliper thanks to profiled edges [12]. Some manufacturers place special antinoise shims in order to reduce the amount of unfavorable noise during braking [13].

The literature analysis allowed to notice that there is a lot of publications devoted to the review of materials for the friction materials production. However, many researchers focus on a narrow range of speciality. Bevilacqua et al. for example focus on catalytic oxidation of carbon - carbon composites used in aircraft brakes [14]. Awasthi and Wood [15] dealt with a similar subject, but much earlier. These articles describes the advantages of these materials and assessed their applicability. Shojaei et al. in turn considered rubber-based composite friction materials. Their main application is for railroad brakes. The influence of rubber-based additives on the thermal conductivity of the final product was also analysed [16]. Fiber reinforced polymers for applications in modern vehicles was the subject of a review by Bijwe [17]. This work presents new achievements in the reinforcement of friction materials with non-asbestos fibers. In India, the focus was on aluminum-alumina arrangement of composite materials dedicated for the automotive industry [18]. This group of materials was developed to replace the harmful asbestos. Kryachek was also involved in the review of composite materials $[19,20]$. In his works detail properties, research methods and results, as well as new methods of obtaining were discussed.

There are also manuscripts by researchers who decided to comprehensively review friction materials and their components. Naresh Kumar and Suman [21] described the research results of various conventional brake pad components in a very broad way. However, there is no information on non-standard materials, e.g. by-products from food production processes. Yang et al. thoroughly described modern nano friction materials in their review [22] However, conventional materials were omitted, which still constitute the vast majority of the brake pad composition. Kato in his manuscript described typical wear behaviors of representative materials of coatings, composites, metallic alloys and ceramics in relation to their friction behaviors [23]. Unfortunately, other material properties have not been described. Chan and Stachowiak [24] made a very good review. They took into account the division of friction materials and described their properties. Unfortunately the article was published quite a long time ago, so it does not include new solutions. The same is the case with other works that require updating [25-27].

As previously stated, the friction material is the most important brake pad layer, as it constitutes, together with the disc, the friction pair, and its composition determines the coefficient of friction and durability of the pad [28]. By taking advantage of the gap in the available materials this review will continue to describe the materials most commonly used in the manufacture of brake pads, and their role and impact on the tribological properties of the final product.

\section{Classification of materials used in the manufacture of brake pads}

Brake pads manufacturers utilise approximately 2000 different materials [29] which have different effects of the final product. An average brake pad consists of from 10 to 20 different substances [30]. Selecting the right composition for the brake pad and predicting its impact on the final products is a difficult task. It requires tremendous amounts of research and abundant experience [31]. The decision must also take into account the intended use of the brake pad, and their operating conditions. The final properties of the brake pad are also shaped by production technology, which is usually the best kept trade secret of every manufacturer. Effective production technology may improve the tribological properties of the brake pad by $100 \%[32,33]$.

The materials used in the production of brake pads can be classified in terms of different criteria. The most important one is the role the substance plays in the process of braking. Based on this criterion there are binders, additives, fillers, and abrasives (Figure 3) [28, 34, 35].

The binder is the flue that hold all the components of the pad. This substance must be characterised by high and stable coefficient of friction, resistance to high and rapidly changing temperatures, and low mass (the binder usually makes up approximately $20 \%$ of the pad volume) [36]. Also, the material must not react with any other component of the pad, as this might lead to changes in overall 


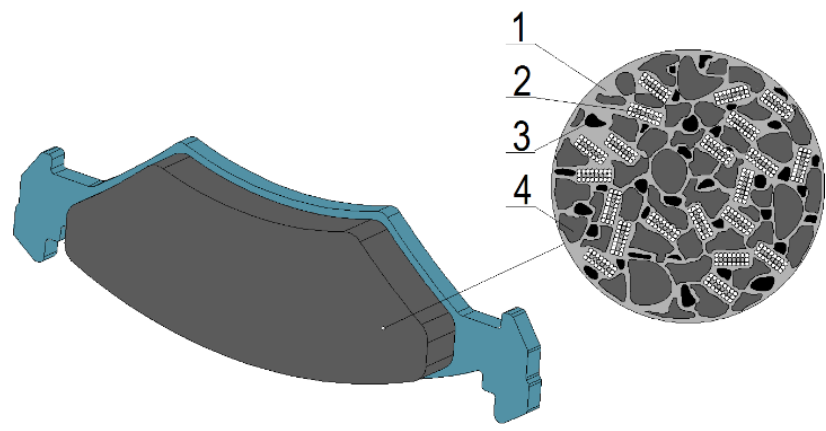

Figure 3: Brake pad friction material structure: 1 - binder, 2 - reinforcement, 3 - filler, 4 - abrasive

material characteristic or cause delamination of the composite and greatly limit the efficiency of the braking system. The binder is usually made from epoxy or silicone resin [24].

The reinforcement is a fibrous material (one or more) which improves the binder's mechanical properties (increasing its strength). Different types of reinforcement materials have a significant impact on the durability and resistance of the brake pad, therefore, the selection cannot be random. In the past, asbestos was an excellent reinforcement fibre. However, due to its harmful properties [37], it was necessary to find a replacement (which today is no problem at all, since there is a whole range of materials which can be used successfully to this end $[38,39])$.

Fillers are used to filling up the empty spaces between the other components of the brake pad. They can make up for up to $10 \%$ of the brake pad volume, which is why using the right substance is so important. Most common fillers include vermiculite, perlite, mica, barium sulphate, and calcium carbonate, due to the substances' resistance to high temperature, lack of reaction with other components of brake pads, and low price [40]. Further on in the work, less common fillers are also analyzed.

Abrasives are used for modifying (increasing or decreasing) the coefficient of friction. Additives such as steel, cast iron, flame resistant oxides and silicates or quartz, due to their hardness, are used for increasing the coefficient of friction between the brake pad and disc, and therefore increasing the operating life of the pad. Additionally, the effect is reinforced by the adhesion with the disc material, especially in terms of metals. The substances also create contact zones, which are the main friction areas in the pair of elements [41, 42]. Unfortunately, due to friction in the contact areas, excessive temperatures are generated. This may lead to destruction of the pad's structure and lead to separation of its components. That is why lubricants are used, which usually improve the thermal conductiv- ity of the pad. Lubricants improve the removal of energy from the contact area and prevent the friction elements from overheating [43-45]. The most common lubricants are metallic sulphates (such as copper or tin) and graphite. Their lubricity depends on the content in the pad (approximately $10 \%$ of volume yields the best results) and the size of lubricant particles [46].

Another criterion of dividing brake pad materials is their origin. In this case, the substances may be natural or artificial. Natural materials include [47, 48]:

- asbestos - a mineral substance not in use today because of its carcinogenic properties [49];

- materials from plants (leaves, stems, or seeds) or animals (e.g. hair, fur);

- and various metals (steel, copper, bronze, cast iron, etc.).

Artificial materials mainly comprise in:

- materials obtained through organic synthesis (e.g. aramids, acrylics);

- synthetic minerals (e.g. mineral wool);

- ceramics;

- and other materials, such as carbon or glass fibres, etc.

Friction materials, mentioned earlier, usually are the dominant component of a brake pad. Based on the type of friction material, brake pads may be categorised as [34, 35]:

- metallic - the main friction material is steel, copper, or some other metal; the pad is characterised by high resistance and thermal conductivity; cooperation with a cast iron disc results in deep scratches and cavities in the material (due to adhesion), and may lead to undesired noise and rapidly progressing corrosion;

- semi-metallic - the friction material is a mixture of metals and organic materials, which provides decent friction and high thermal conductivity; similarly to metallic pads, wear may be more rapid, as well as noise during braking and corrosion;

- non-asbestos organic or ceramic - the main component in this case is an organic material usually reinforced with aramid, glass or ceramic fiber; this design ensures high durability, resistance to high temperature, low wear rate, light weight and quiet operation; however, due to the complexity of the production process, this type of solutions may be very expensive, and because of high hardness, the material may be brittle; 
- carbon-carbon - structure of the pad is similar to that of ceramic pads, yet its properties are more desirable, namely: high coefficient of friction, resistance to increased temperatures and wear, small weight; this type of brake pad works best in elevated temperatures, that is why it is often used in sport cars; manufacturing costs, compared to conventional brake pads, are very high;

- eco-friendly - one of the main components (additives) in these type of brake pads are plant-based materials, usually waste material obtained in the production of, for example, food; brake pads with this type of material have various properties, usually favourable ones (small weight, low costs, environmentally neutral, high durability, resistance to friction).

\section{Characteristics of selected materials used in the manufacture of brake pads}

\subsection{Binder}

As a binding material, resins are often used as binders. They must be added in precisely determined amounts, as only then will they properly serve their desired function [50]. Too little resin reduces the durability of the pad, too much resin may reduce the coefficient of friction in high temperatures and significantly increase hardness [51, 52]. Resin is one of the most important components used in the manufacture of brake pads, as it binds all of the other components of the pad, allowing them to effectively cooperate. However, when excessive heat is generated during braking, the quality of the material of the brake pad may deteriorate. This is related with degradation of resin resulting in the substance losing its binding properties [53]. That is why the thermal stability of a brake pad, its capacity for maintaining mechanical properties and capacity for binding components in unfavorable conditions of braking may largely depend on the resin [54]. In order to improve the original mechanical and thermal properties of resins, numerous attempts at modifying its composition are made $[55,56]$.

Phenol resins are the most often filler produced almost exclusively for the purpose of friction materials. They have hardly any other uses. The weight fraction of phenol resin in a brake pad ranges from 5 to $35 \%$ of volume. The amount of content affects the coefficient of friction value and the ware rate inversely. The COF value change is only a few percent heaving about $10 \%$ drop in the wt. pad resin content [57]. Its common use in the automotive industry stems from the resins favourable properties, such as high mechanical resistance and low price [58]. What is also important, this type of resin has a low thermal expansion. Compared to other resins, it is also more resistant to solvents, acids, and water, and generates less smoke during combustion. The temperature of the initial degradation, which is very important because of correlation with the phenomenon of the brake pad fading, decreases from $354^{\circ} \mathrm{C}$ of the pure resin to $303^{\circ} \mathrm{C}$ of the cured friction material [59]. Unfortunately, the material is brittle. Susceptibility to cracking may be reduced by adding oil or silicone gum. This produces silicone resin. However, in the process other mechanical properties suffer [29]. Phenol resin is not the best material for high temperature friction. During sudden braking, the temperature of the pad may easily

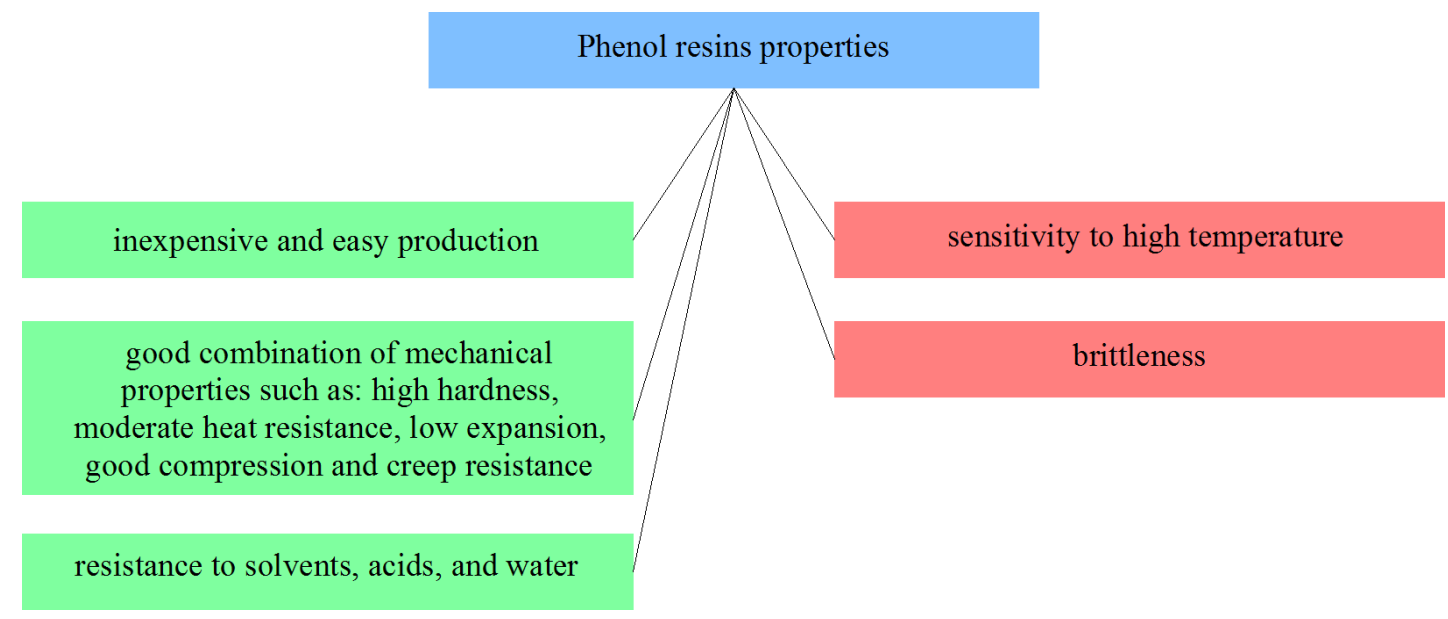

Figure 4: Selected phenol resins properties from the point of view of applicability in friction materials 


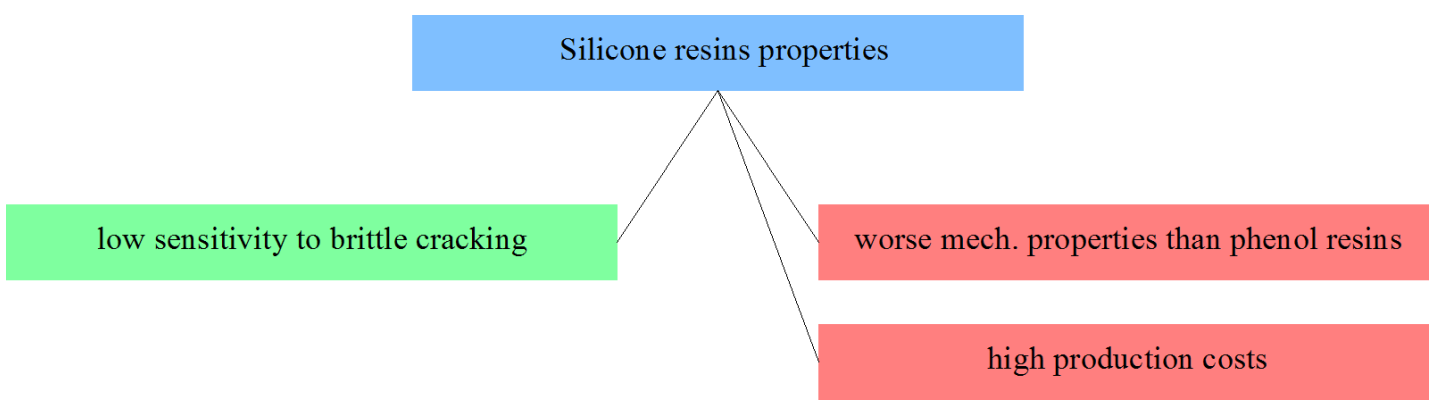

Figure 5: Selected silicone resins properties from the point of view of applicability in friction materials

reach $700^{\circ} \mathrm{C}$, greatly exceeding the degradation temperature of phenol resin $[60,61]$.

COPNA resin demonstrates slightly improved thermal resistance. Although its disintegration temperature is similar $\left(400-500^{\circ} \mathrm{C}\right)$, significantly less gas is released in the process. This reduces the risk of brake fading. Also, as the particle is similar to graphite, the two materials bind together excellently. This improves the pad's friction resistance $[62,63]$.

Cyanate ester resins are made from cyanide monomers. These resins are chemically neutral and demonstrate a tendency to damper vibration. However, its most important property is resistance to high temperatures. Research has shown that enriching it with $\mathrm{ZrB} 2$ in the amount of about 5\% improves thermal stability and ensures optimal tribological properties related to the COF and wear rate [64]. Experiments were also carried out with admixture of graphite and $\mathrm{MoS}_{2}$. That way scientists obtained an improvement in mechanical properties and a decrease in the wear rate [65]. The high cost (resulting from a complicated and often multi-day production process [66]), on the other hand, is one of its main drawbacks. That is why it is rarely used in friction materials. Cyanate ester resins find more applications in electronics $[67,68]$.

Epoxy resins are very commonly used in the industry. Their low resistance to heat (degradation starts at approximately $260^{\circ} \mathrm{C}$ ) make them unfit for friction materials [69]. The results of some researchers show that even at a temperature of $100^{\circ} \mathrm{C}$, a weight loss of about $7 \%$ can be noted [70]. This mass loss can be associated with the formation of volatiles during firing. Continued heating above $400^{\circ} \mathrm{C}$ led to the formation andoxidation of carbon. However, inter-

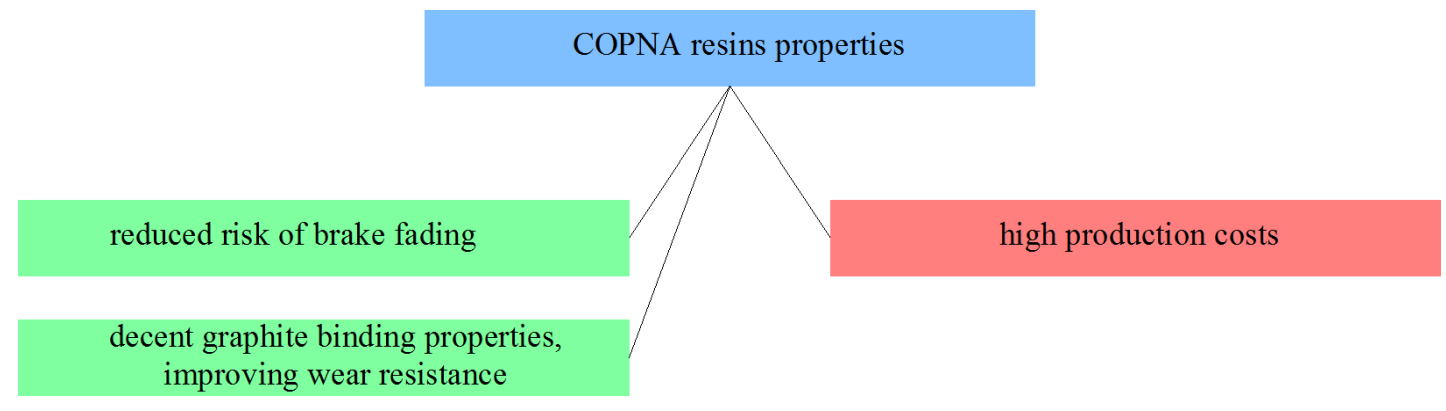

Figure 6: Selected COPNA resins properties from the point of view of applicability in friction materials

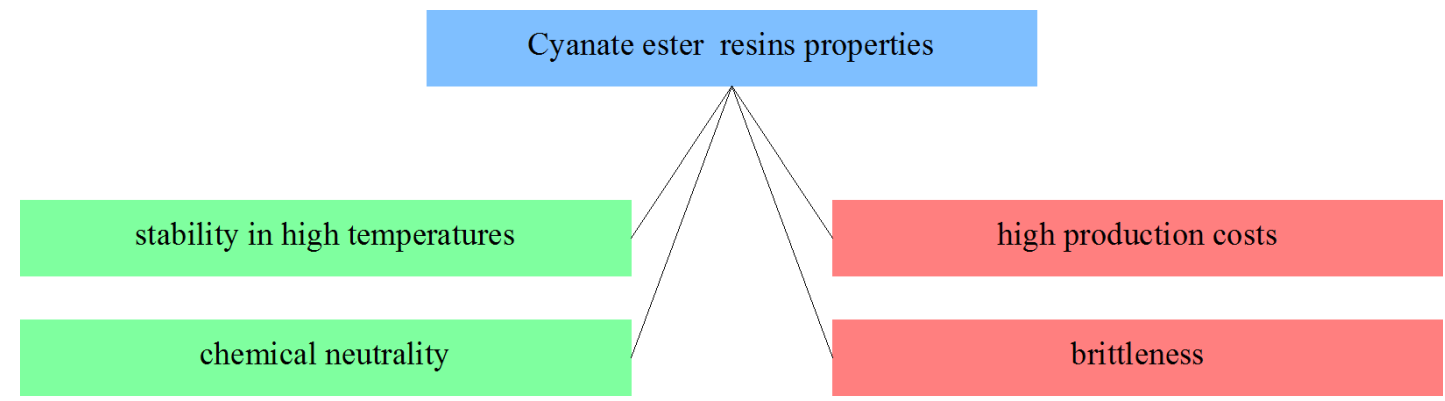

Figure 7: Selected cyanate ester resins properties from the point of view of applicability in friction materials 
good mechanical properties and high thermal resistance when combined with phenol resins

\section{Epoxy-modified resins properties}

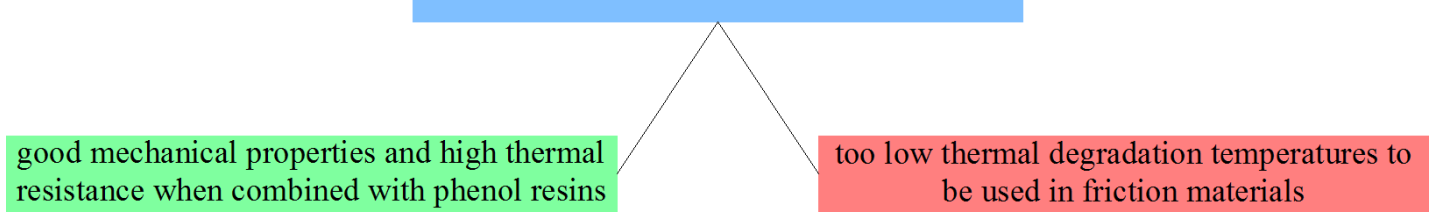

Figure 8: Selected epoxy-modified resins properties from the point of view of applicability in friction materials

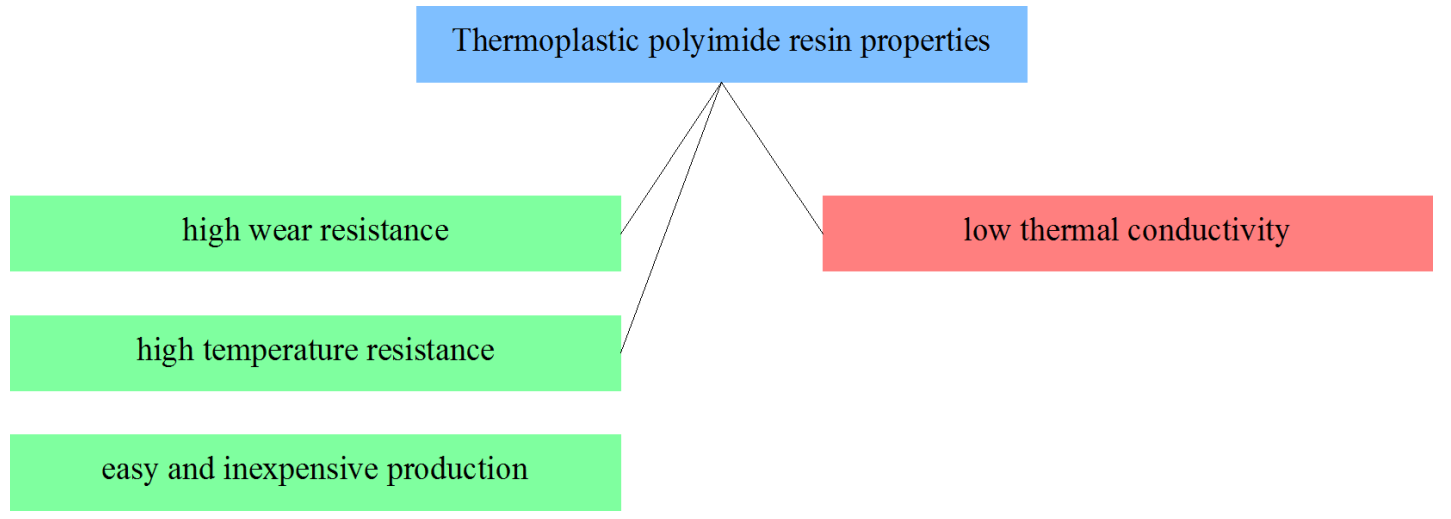

Figure 9: Selected thermoplastic polyamide resins properties from the point of view of applicability in friction materials

esting results are obtained when epoxy and phenol resins are combined. The material is far more resistant to high temperatures, and has better mechanical properties than the two resins [69].

Thermoplastic polyamide resin is a product obtained from fluoresin and calcium carbonate. It is resistant to wear and high temperatures. Also, the production process is inexpensive and easy. However, the resin is a good thermal isolator (approximately three times better than phenol resin). That is why its usefulness in the manufacture of brake pads is very small [69].
Metal matrix composites are increasingly found in the latest solutions of the automotive industry. These matrices are used not only in braking systems, but also in clutches [71], intake systems [72], engine blocks [73], or fuel system elements, mainly classic injectors using piezoelectric stacks [74, 75], as well as alternative fuels injectors [76]. These composites are also used as a partial or complete replacement for conventional materials in the production of monoqocue type frames [77]. In brake systems, metal matrix composites are usually used for the production of brake drums and discs, both in cars [78-80]

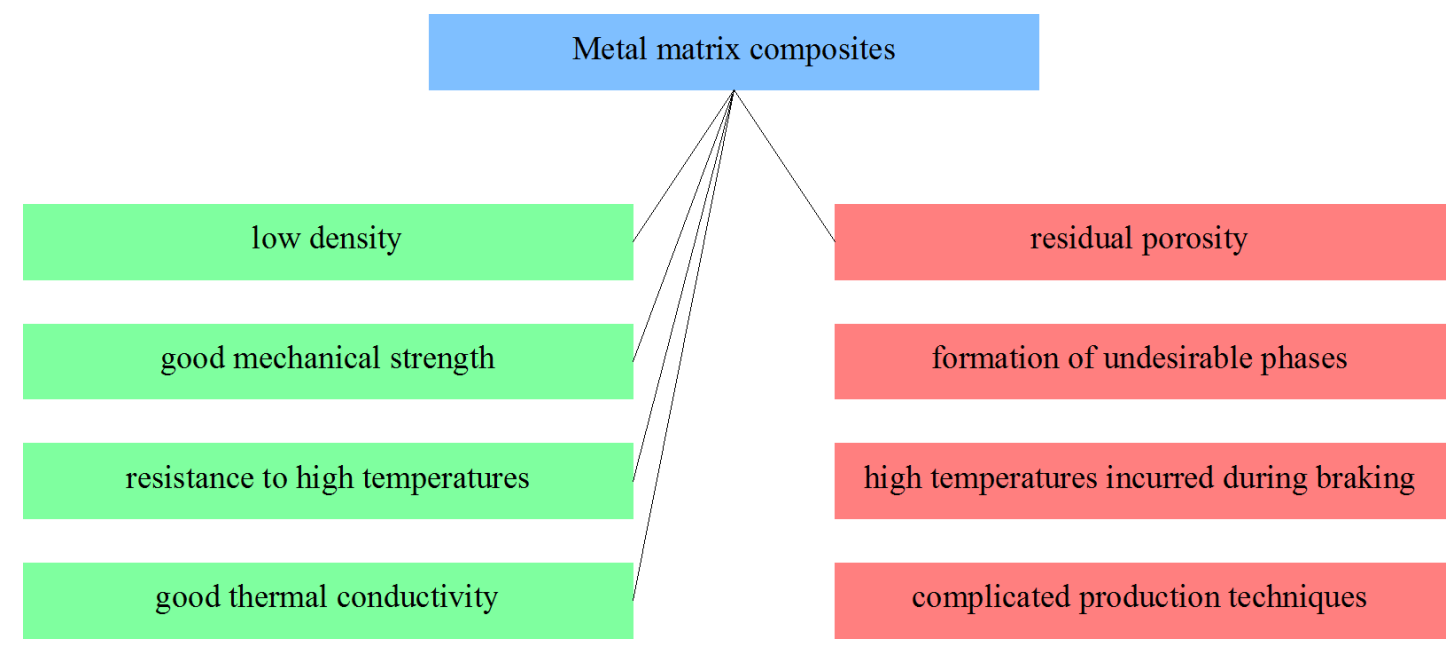

Figure 10: Selected MMC properties from the point of view of applicability in friction materials 
and in other types of vehicles, such as motorcycles [81]. In the friction linings of brake pads, mostly aluminum-based materials reinforced with, for example, silicon carbides, are used [82]. Their excellent properties such as: low density, good mechanical strength, resistance to high temperatures and good thermal conductivity [83-85] are features that are desirable in brake pads. Unfortunately, materials of this type also have their drawbacks. Issues with uniformity of distribution of SiC particulates, residual porosity, formation of undesirable phases such as aluminum carbide, and high temperatures incurred during braking effectively limit their common use in brake systems [85]. The last feature is related to the high coefficient of friction when cooperating with other materials, and overheating may lead to material degradation [86]. Very important issue is related with MMC production techniques: liquidmetal-mixing processes (incorporation of reinforcement particles or short fibers into a molten or semi-solid aluminum matrix through a stirring process), liquid-metalinfiltration processes (molten aluminum or its alloy is moved into a preform of the reinforcement, either as a packed bed or a rigid, free-standing structure) and solidstate processes (e.g. powder metallurgy) [87]. These are methods that require far more sophisticated equipment and deeper knowledge than those used in the production of resin-based friction materials.

\subsection{Reinforcement}

Aramid is a material made from rigid molecular chains oriented along fibre axes. This structure makes it possible to utilise the covalent bonds along the polymer, producing a high Young modulus and durability higher than steel wire of the same weight [88-90]. It is sold under many trade names, the most popular of which is Kevlar. Aramid fibres are an excellent alternative to asbestos. That is why they are used as reinforcement in brake pads [91]. The material performs well in high temperatures, which has a positive effect on the stability of the coefficient of friction [92]. Unfortunately, the use of aramid reduces the coefficient of friction even by half. On the other hand, the wear rate is improved by up to ten times [93, 94]. Importantly, changing the percentage of aramid content does not cause a linear change in the properties of the final material. Research has shown that an aramid fiber content of $6 \%$ of total volume is the optimal solution. The value of coefficient of friction doesn't change much with temperature rising. Its value is approximately $0.41[95,96]$. The use of Kevlar mixed with glass or steel fibres is an interesting solution. This produces a hybrid material which is cheaper than pure aramid and provides favourable properties confirmed in numerous studies [97-99].

Glass has been used in the industry for a long time. With the ban on asbestos, the automotive industry started researching the use of glass (in the form of glass fibres) as a suitable substitute $[100,101]$. The results obtained by some researchers indicated that the material has positive mechanical properties (especially hardness and abrasion resistance) [51, 102]. The highest values of COF (0.41-0.44) were obtained for samples with $5-10 \mathrm{wt} \%$ of glass fibers content. The samples also consisted of: silicon carbide, coconut fibre, graphite, alumina oxide, zirconia oxide and resin [103]. On the other hand, it was also observed that, depending on the operating temperature, the pad materials with glass fibre content have varied capacity for creating film on the brake disc. This results from the destruction of the binder and "pulling out" of fibres, which then deposit on the friction pair $[104,105]$. This may lead to increased degradation of the pad, undesired vibration and noise, especially in high ( $10 \%$ volume) glass fibre content. Researchers believe this is also caused by the brittleness of glass. These negative features were partially reduced by the use of shorter fibres $[100,106,107]$. Aranganathan et al. discovered that the size of the glass fibers used to produce the friction material is also important. Milled glass fibers exhibited a higher coefficient of friction, high wear rate, and larger oscillation amplitudes during stick - slip

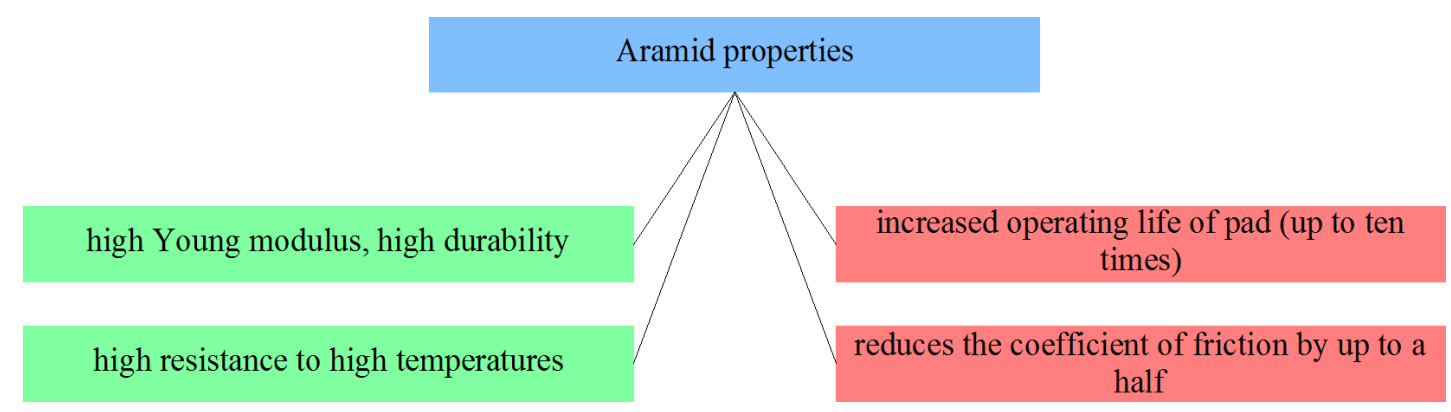

Figure 11: Selected aramid properties from the point of view of applicability in friction materials 


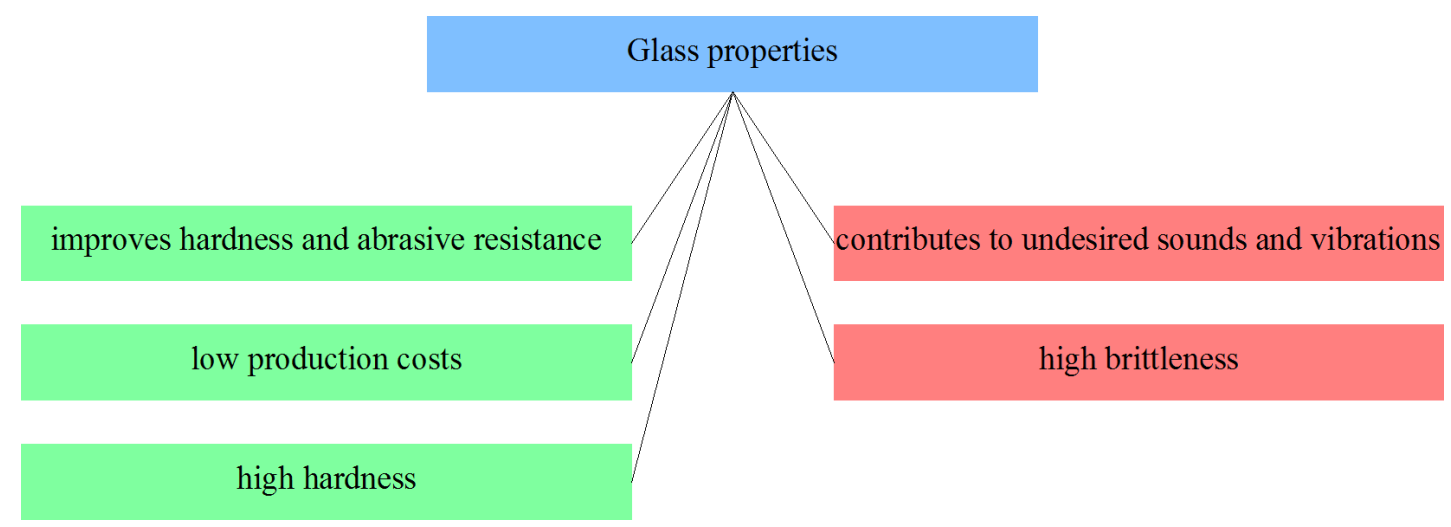

Figure 12: Selected glass properties from the point of view of applicability in friction materials

experiments, which was attributed to the higher static friction due to the smooth surface. The friction materials with milled glass fibers, therefore, can have a higher propensity for friction-induced vibration during brake applications [108]. It is also worth noting that glass has a high melting temperature (over $1400^{\circ} \mathrm{C}$ ) and is a good thermal insulator [109]. While the former property is beneficial in brake pads as it stabilizes the coefficient of friction, the latter one is rather avoided.

Cocoa beans are chiefly used in the food industry. The outer shell of the bean (Cocoa Bean Shells - CBS) is a food processing waste material, a by-product. Because it is a low density fibrous material, it was attempted to use it as a substitute for asbestos. Non-toxicity of the material is one of its greatest advantages [110, 111]. In many countries (such as Nigeria) it is very cheap and easily available, and using it in the automotive industry solves the problem of utilization [112]. Olabisi et al. studied the density, water and oil absorption, abrasion resistance, coefficient of friction, thermal conductivity, hardness, as well as compression and tensile strength of three groups of pads, in which the CBS content was 21,26 , and $31 \%$ volume. The results were compared with the average values obtained in testing conventional brake pads. The researchers observed that CBS fibre content increases the pad's capacity for water and oil absorption. All of the studied material also showed lower density in comparison to conventional brake pads, which had a positive effect on the weight of the final product. It was also shown that the pads have lower coefficient of friction and abrasive wear rate. This increased the durability of the brake pad. However, cocoa bean shell fibres do demonstrate decent thermal conductivity, compared to pads based on other components. Despite low hardness, brake pads containing CBS (especially higher contents) showed improved resistance properties, compared to conventional pads [112].

Palm Kernel Shell is a waste material obtained, for example, in the production of palm oil used in margarine.

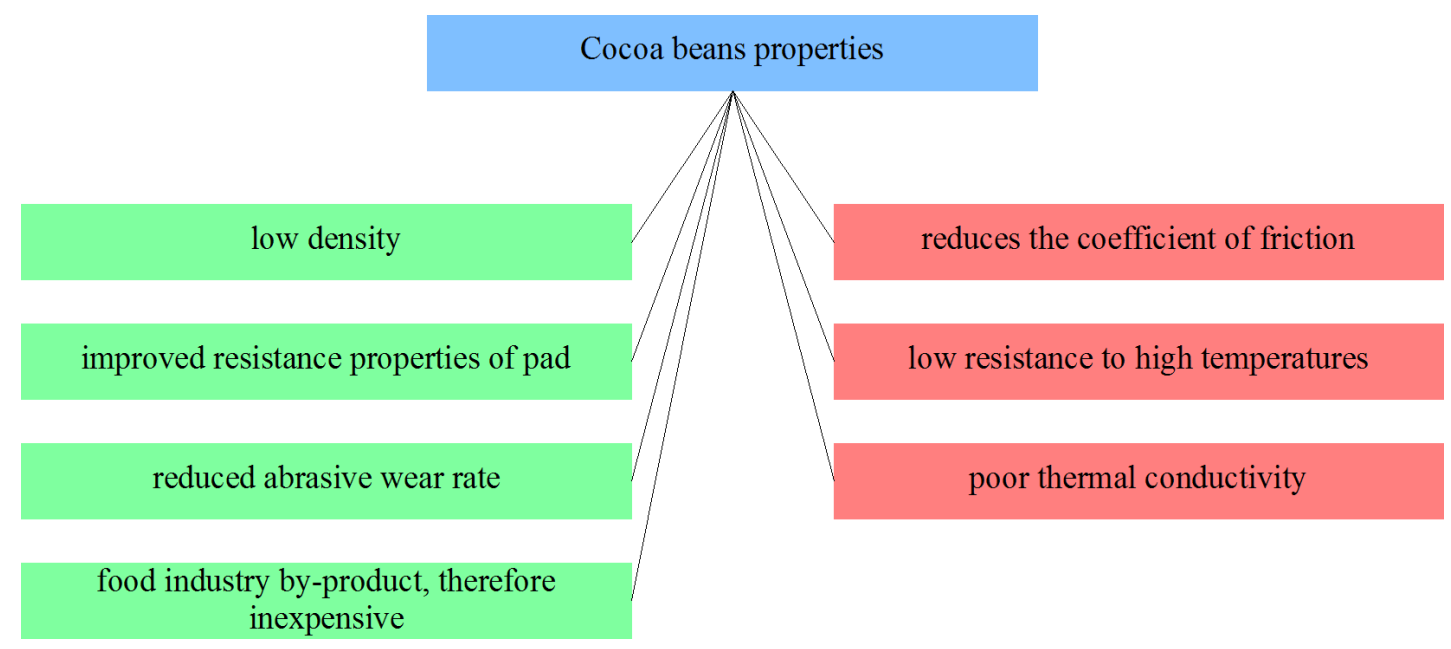

Figure 13: Selected cocoa beans properties from the point of view of applicability in friction materials 


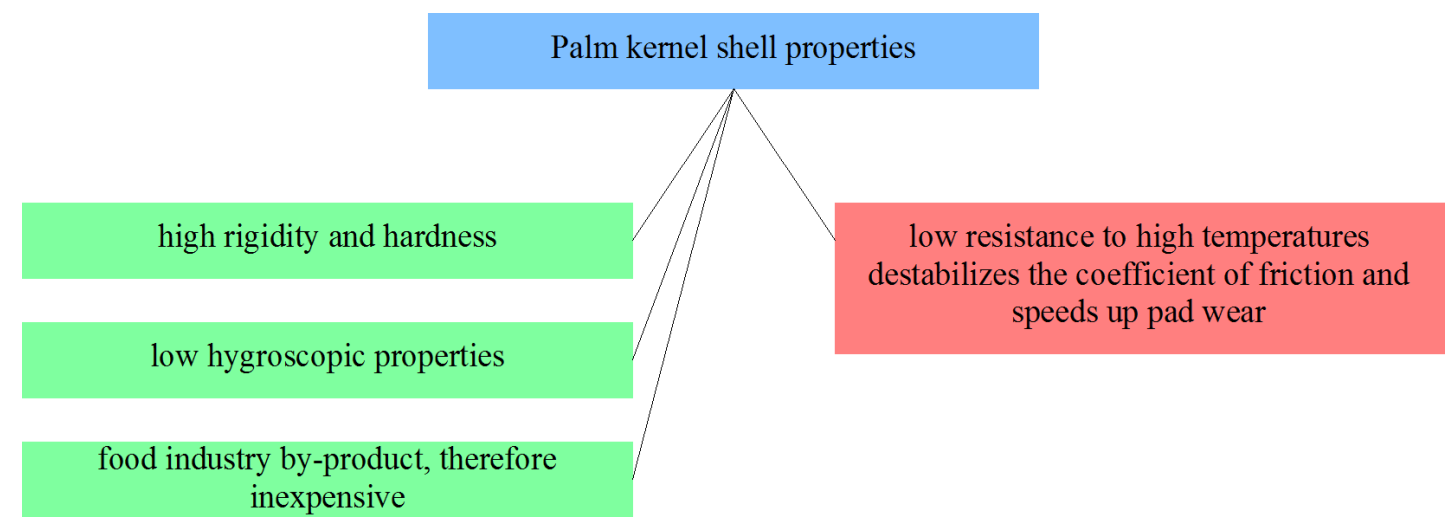

Figure 14: Selected PKS properties from the point of view of applicability in friction materials

Palms are mainly grown in plantations in West Africa. 1518 ton yield per hectare make PKS (Palm Kernel Shells) an abundant and cheap material. Its low density (compared to other organic waste) makes it easy and inexpensive to transport [113]. PKS, due to its fibrous structure, is used as an asbestos substitute in brake pads. Their content can reach even $40 \%$ of the friction layer volume [114]. Pulverized particles demonstrate low hygroscopic properties and high stiffness and hardness, which are favourable properties in brake pads [115]. They are also characterised by high coefficient of friction (approximately 0.41) with a cast iron brake disc. However, due to its low resistance to high temperatures, it was shown that during braking from high speeds the coefficient of friction significantly decreased. Oxidation also increased the wear of the pad, which was significantly quicker in comparison to commercial brake pads [116, 117]. Conducted by Mgbemena et al. research showed the following onset temperatures for the three phases: $54.28^{\circ} \mathrm{C}, 237.14^{\circ} \mathrm{C}$ and $538.57^{\circ} \mathrm{C}$ respectively and considerable weight loses of $6 \%, 27 \%$ and $42.37 \%$ [118]. Test of brake pads intended for "cold" braking, which does not produce temperatures in the hundreds of degrees $\mathrm{C}$, yielded far more success. The size of the PKS particle used in the production of the pad is also important. Brake pads containing larger particles showed improved hygroscopic absorption and better wear resistance in tests. The best mechanical properties (i.e., high hardness and resistance and low porosity) was obtained when using finely pulverized PKS [119].

Banana peels constitute up to $40 \%$ of the total weight of a fresh banana [120]. Currently the peels are used as fertilizer or discarded as waste [121]. According to the criteria established by the National Cancer Standard Institute [122], banana peels are classified as non-toxic for human tissues, and therefore can be safely used in various industries. Physical and chemical tests on banana peels showed that they are mainly made of antioxidants and pectin [123]. Pectin substances are complex polysaccha-

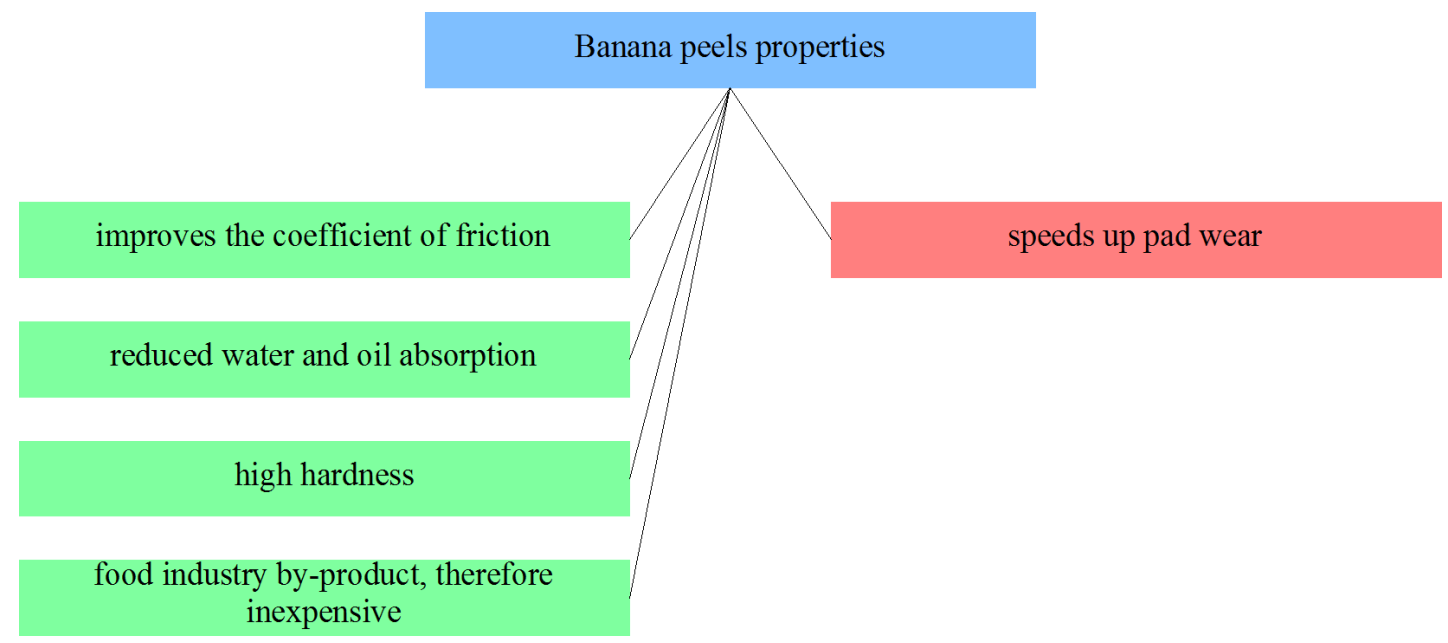

Figure 15: Selected banana peels properties from the point of view of applicability in friction materials 
ride mixtures containing galacturonic acid units as the main chain acting as the gel forming agent. The harness of the substance is further increased by adding banana peel powder. It was observed that as temperature increases, the powder initially becomes more gelatinous, and then hardens [124, 125]. Because of these properties, banana peels can be used for forming novel brake linings, increasing the capacity of binding resin in high temperatures. Experimental tests confirm these claims. Sufficiently strong bonds between powdered banana peels resulting in an increased coefficient of friction [126]. Additionally, the material showed low water and oil absorption. However, brake pads containing banana peels wear more quickly [125].

Periwinkle shell is the most unusual material used in the production of brake pads presented in this paper. The shells of these tiny animals are a waste by-product of food processing. Due to the huge amount of waste produced in the process, it is believed to be a threat to the environment and human health. The use of fragmented shells (as an alternative to asbestos) in the production of brake pads may partially reduce the issue of utilization. Scientists in Nigeria studied the mechanical properties of the shells using pulverized material with particle size under $255 \mu \mathrm{m}$. Their research showed that the material has lower density than asbestos and is quite resistant to high temperatures. First signs of thermal degradation were observed at temperatures exceeding $6000^{\circ} \mathrm{C}$. It was also shown that the studied material is harder (approx. 75 HRC) than asbestos [127, 128]. Other researchers, also based in Nigeria, went further and produced a range of brake pad prototypes using various sizes of periwinkle shell particles (ranging from 100 to $350 \mu \mathrm{m}$ ). The studies showed that $100 \mu \mathrm{m}$ particles offer the best properties. They presented the best compression resistance and hardness, and lowest water and oil absorption. According to the authors, the parameters are better than those of commercial brake pads [129]. The results were confirmed by Amaren et al. In their research, the smallest fractions $(125 \mu \mathrm{m})$ gave the best abrasive wear resistance results [130].

Ceramic composites are materials made in at least two phases: the binder and the reinforcement (component) embedded in the binder. One of the most common combinations used in the automotive industry is silicon carbide (the binder) and carbon fibre (the reinforcement supporting the structure). Thanks to their structure, ceramic composites are characterised by favourable mechanical properties, such as high durability and resistance to wear (the operating life of braking systems utilising $\mathrm{C} / \mathrm{SiC}$ may be five times longer compared to conventional solutions), resistance to high and rapidly changing temperatures, low thermal expansion, and light weight [131]. The main disadvantage of this type of material is the instability of the COF. Research has shown that depending on the friction conditions, the COF value can vary from about 0.2 to even 0.8 [132]. Moreover, production process requires specialised equipment and is time consuming, resulting in a costly final product [133-135]. Another group of materials combine aluminium alloys and silicon carbide ( $\mathrm{Al} / \mathrm{SiC})$. This type of composite is supposed to reduce inertia (which is particularly important for brake discs) and noise, and to increase wear resistance, as well as harmonise the friction mechanism. Additionally, the use of $\mathrm{Al} / \mathrm{SiC}$ composites makes it possible to control heat conductivity by selecting the content and distribution of the reinforcing material $[136,137]$. Unfortunately, few brake pad manufacturers have yet introduced this type of product.

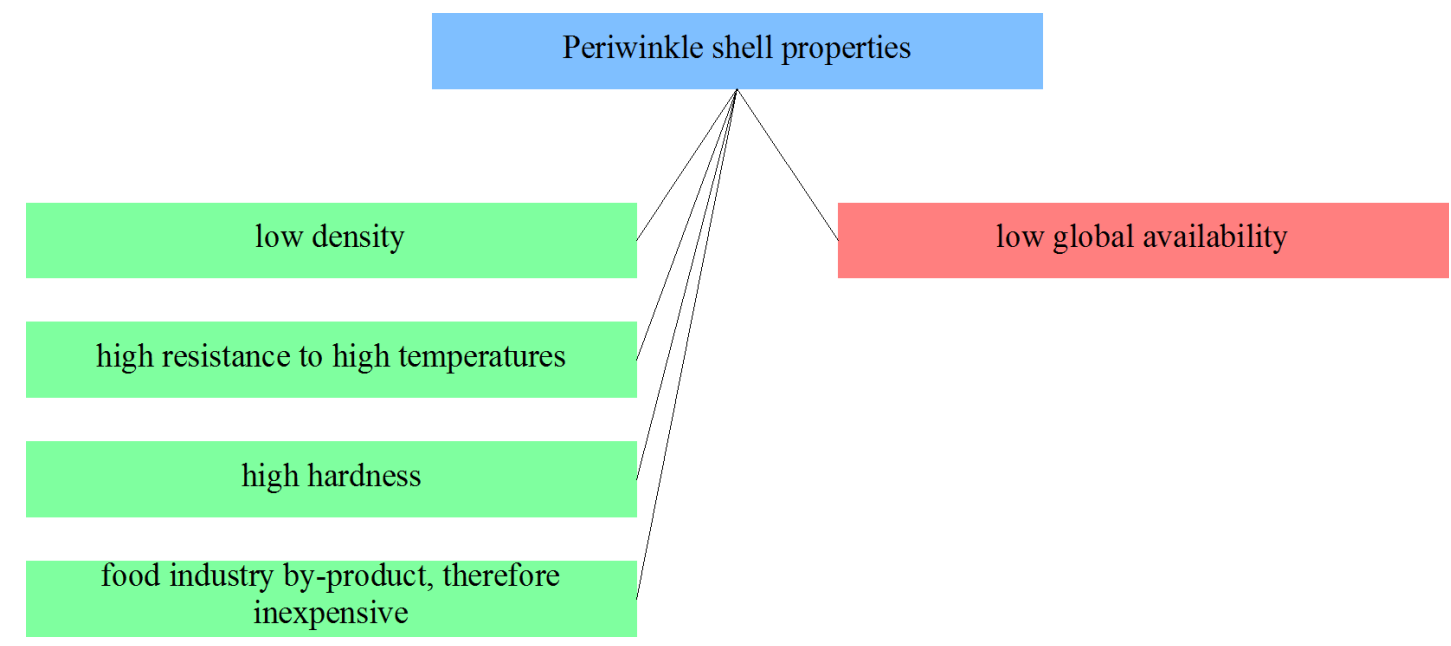

Figure 16: Selected periwinkle shell properties from the point of view of applicability in friction materials 


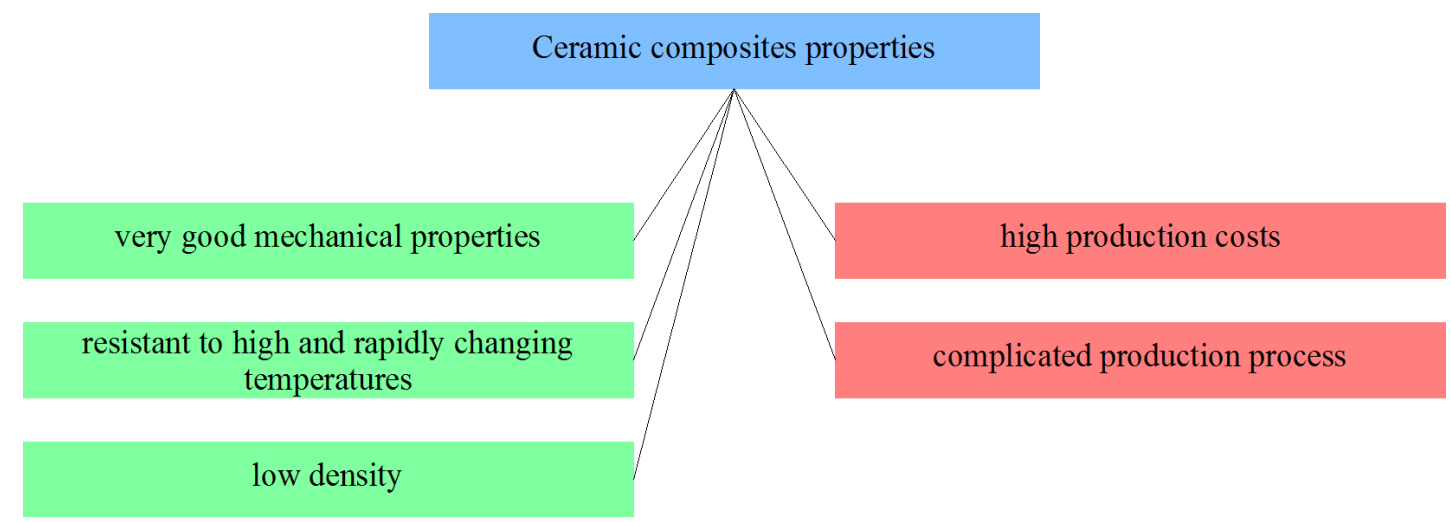

Figure 17: Selected ceramic composites properties from the point of view of applicability in friction materials

\subsection{Fillers}

Barite is a mineral mined in several locations around the globe. It shows high density and tribological properties which change only slightly with rising temperatures. The availability of the mineral makes significantly reduces its cost. Barite is used as a brake pad filler [51]. Sugözü and Dağhan showed that as the barite ratio in a brake pad increases, the wear rate reduces, despite the mineral's resistance to abrasion. It also reduces the coefficient of friction [138]. El Soeudy et al. add information, that barium sulfate has a little effect on the negative gradient of the coefficient of friction (its value is from 0.3 to 0.7 depending on composition of the sample) with sliding velocity and rubbing pressure changes. They also discovered that increase of $\mathrm{BaSO}_{4}$ content in friction material causes high stability of the coefficient of friction (high fade resistance) and leads to better wear rate (low wear resistance) [139]. Moreover, barite is resistant to high temperatures. Laboratory tests have shown that it does not significantly change its properties at temperatures above $300^{\circ} \mathrm{C}[140]$.
Fly ash is a by-product of coal combustion in industrial factories and heat and electricity plants. It has the form of fine mineral dust, light to dark grey or light brown colour, and is mainly composed of silicon, aluminium, and iron. Also, fly ash contains various trace elements, similarly to natural rock, and has small content of unburned carbon [141]. Coal combustion has a negative impact on the environment, which is why waste product management, especially in terms of industrial waste, is an environmental policy priority in many states. Different types of coal and varieties of power boilers result in fly ash with changing properties, which impacts the waste management process [142, 143]. As the material is cheap, it was attempted to use it as a filler in brake pads. The mass content ranges from several percent to $55-60 \%$ of total weight [144, 145]. Research showed that brake pads with high ash content have stable coefficients of frictions, but only for low initial speeds of the vehicle. Some researchers observed that after reaching a limit value (the tests were based on braking from an initial speed of approx. $100 \mathrm{~km} / \mathrm{h}$ ), the coefficient of friction significantly decreased [146]. This could be the result of using other materials, which are not as resis-

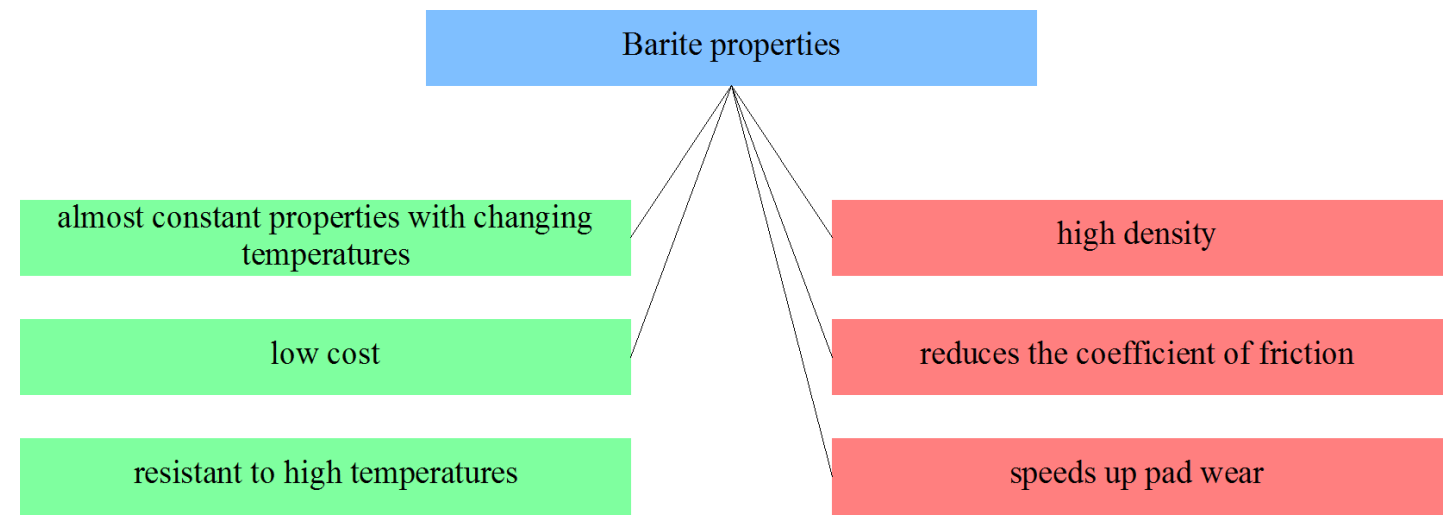

Figure 18: Selected barite composites properties from the point of view of applicability in friction materials 


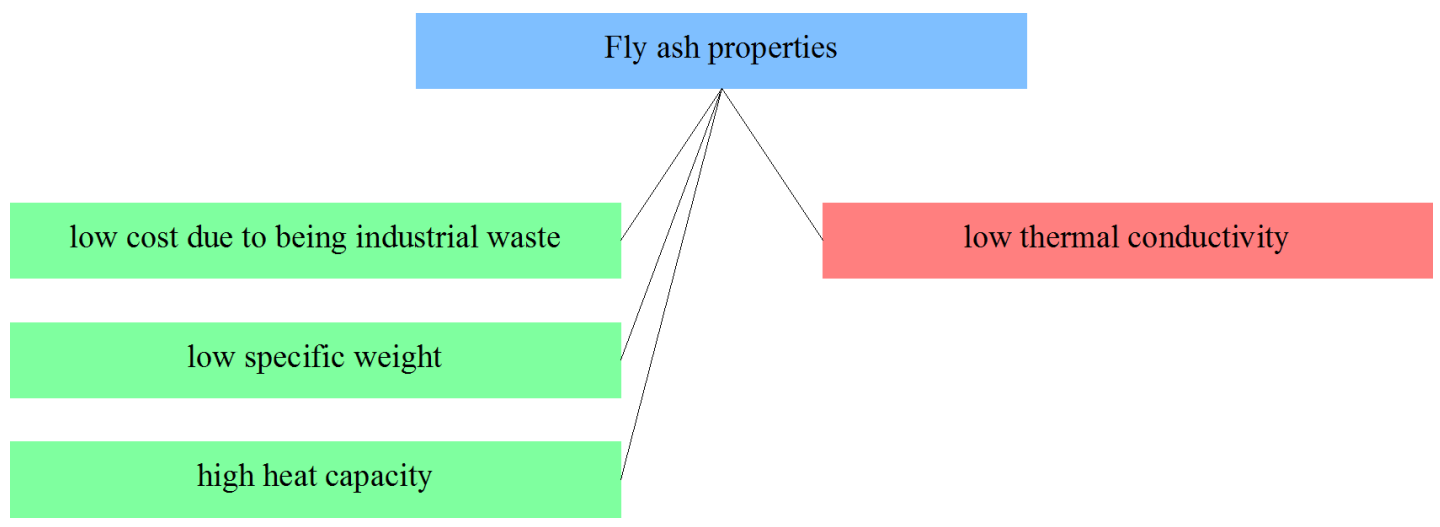

Figure 19: Selected fly ash composites properties from the point of view of applicability in friction materials

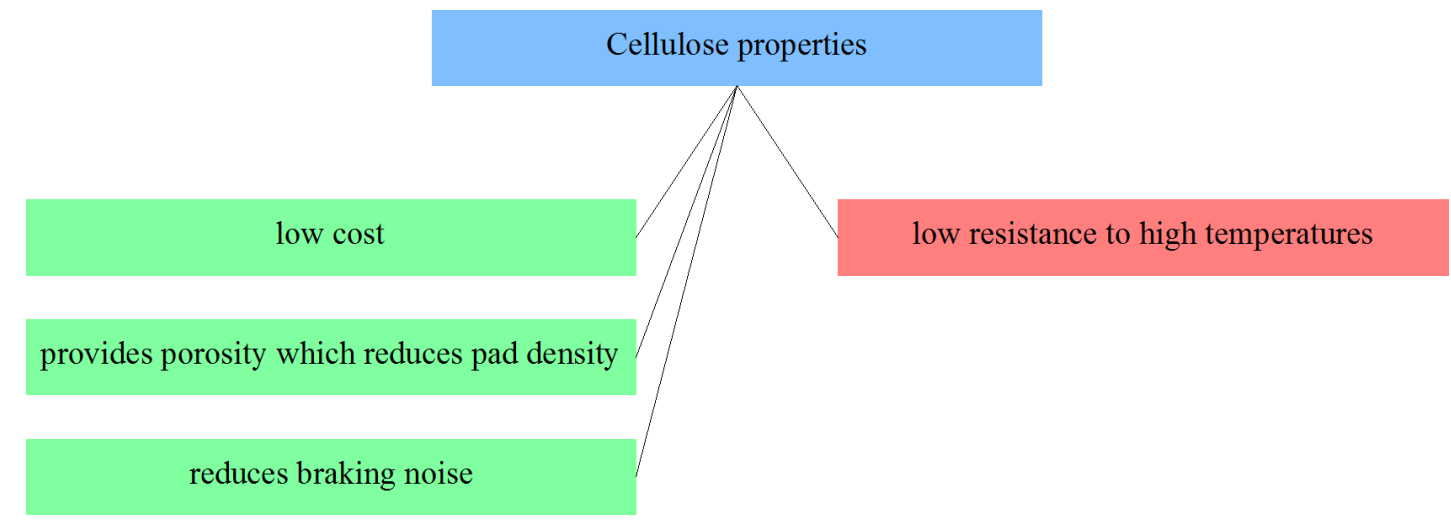

Figure 20: Selected cellulose composites properties from the point of view of applicability in friction materials

tant to high temperatures. Different results were obtained by Sugözü. In his research, the value of the coefficient of friction in cooperation with cast iron is constant, or even rising with the temperature. It reaches little more than 0.3 at operating temperatures of $200^{\circ} \mathrm{C}$. The sample used in the study contained $46 \%$ of ash [147]. Choosri et al. in turn had the best results for samples containing only $4 \mathrm{wt} \%$ of considered material [148]. The results are not unequivocal, therefore it can be assumed that the selection of the other components of the abrasive material has a decisive influence. Fly ash itself does not change its properties with rising temperatures [143]. Ash has a positive effect on thermal energy management. Brake pads with a $55 \%$ volume ash content were less susceptible to heat than commercial pads. This results from high heat capacity of fly ash (up to $800 \mathrm{~kJ} / \mathrm{kgK}$ ), thanks to which ash particles store heat, and its low thermal conductivity $[143,144,146]$. One of the benefits of fly ash is their specific weight, which is two to three times lower than other brake pad components. This means that the use of ash makes it possible to reduce the weight of the pad $[143,144,149]$.

Cellulose is an organic material obtained from trees. It is most commonly added to brake pads in powdered form.
The manufacture of brake pads usually involves high temperatures, burning the cellulose. This results in a porous material, which reduces the density of the final product. Also, the noise of braking is reduced [51]. Marewad et al. stated that the friction material containing $10 \mathrm{wt} \%$ microcellulose fibres showed comparable results with the commercial brake pads. The wear rate of the prepared by them material was found to be $3.7 \mathrm{mg} / \mathrm{m}$. COF value was determined to be 0.357 . They also say that thermal stability of prepared composite samples was very good up to $500^{\circ} \mathrm{C}[150]$. However, this is rather due to the other components. So far in the automotive industry, cellulose friction materials are used in the production of specific types of clutches [151].

\subsection{Abrasives}

Copper is one of the basic components of brake pads. The effects of copper on the tribological properties of brake pads is strongly related to the copper content [152-154]. Research showed that fractions lower than $4 \%$ of volume do not yield significant results. Brake pads with more than 


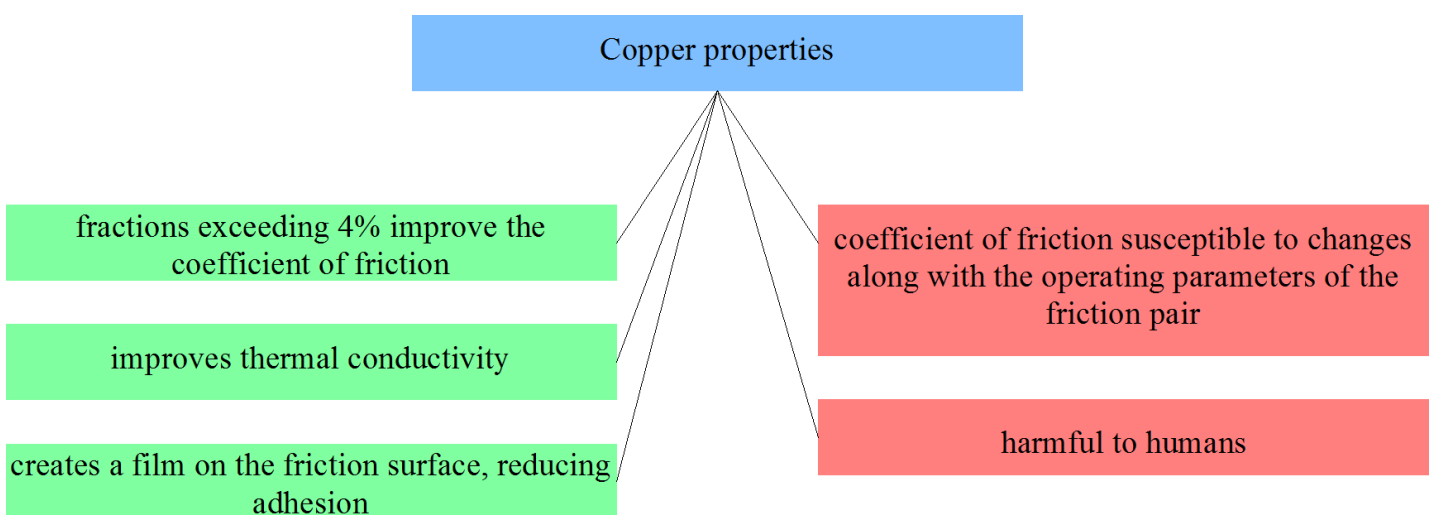

Figure 21: Selected copper composites properties from the point of view of applicability in friction materials

4\% copper demonstrate an increased coefficient of friction. Drawbacks of using copper include a changing coefficient of friction as the pressure and speed of friction changes, demonstrated by many researchers [155-157]. A changing coefficient of friction may produce undesired noise [42]. Copper, like cast iron, creates contact zones during friction. This is because, despite being a soft material, copper is still usually harder and more resistant to abrasion than the binder. During abrasion it creates a film on the corresponding surface, increasing thermal conductivity and heat resistance of the brake pad [158]. Adding copper to brake pads may also support the process of recycling devices with electrical motors. The motor wiring can be simply cut into $1-2 \mathrm{~mm}$ pieces and provide a ready material for brake pad production [107]. Powdered copper is also used, with nano- $(50-200 \mathrm{~nm})$ or micro- (400$600 \mu \mathrm{m}$ ) particles [159]. Unfortunately, copper is harmful to humans and some states introduce regulations limiting the allowable fraction in brake pads. There is a need for a substitute material, which is successfully met by graphite and titanium mixtures. Additionally, the resulting material demonstrates reduced braking noise [42].

Boron is metalloid which is very commonly used in the industry. It is characterised by a high melting point. Also, it demonstrates low chemical activity. Boron is a good thermal and electrical isolator. Due to its advantageous properties it was studies as a friction material. Boron fraction in brake pads usually does not exceed $2 \%$ of volume. It is hard and therefore improves the durability of the pad, which corresponds to increased wear resistance [160]. Numerous researchers who studied brake pads containing boron observed that the element increases the coefficient of friction. However, it was also observed that when temperatures exceed $100^{\circ} \mathrm{C}$, the coefficient significantly drops. This phenomenon may be explained by reduced hardness and melting of another component - aluminium [161-163]. On the other hand, it was observed that the coefficient of friction changes in a predictable manner, and the value decreases in a more stable and repeatable way compared to commercial pads $[163,164]$. However, because of low

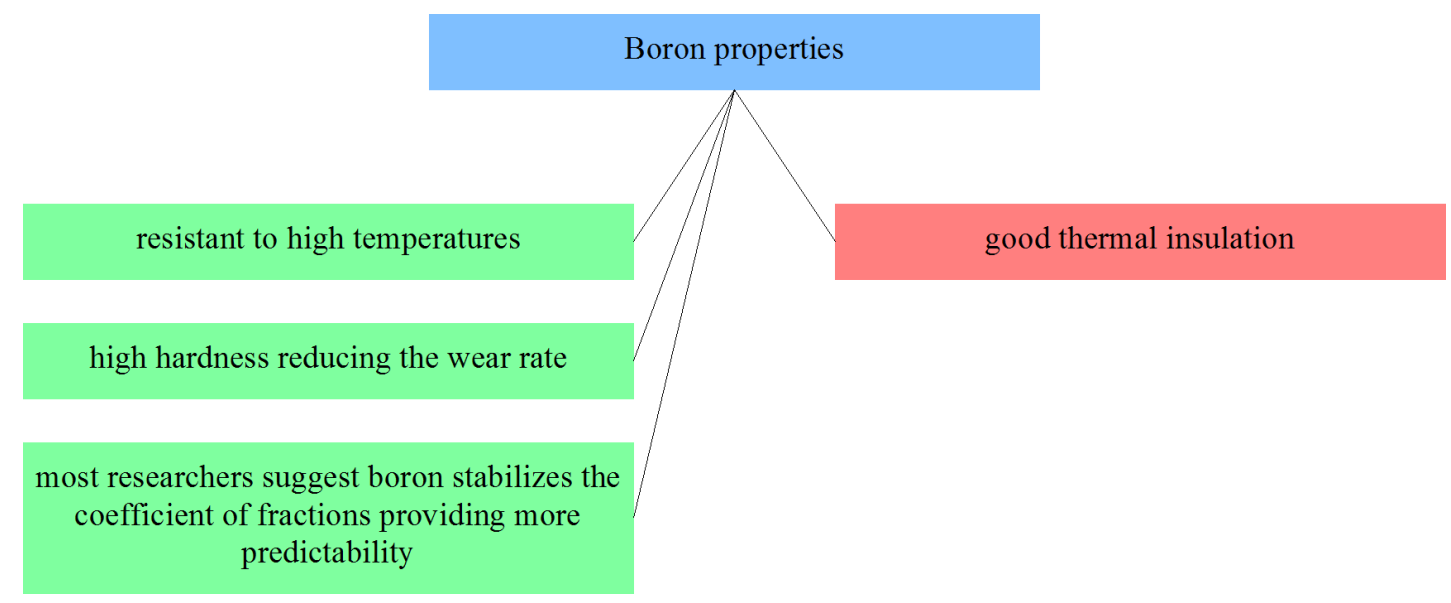

Figure 22: Selected boron composites properties from the point of view of applicability in friction materials 
thermal conductivity, boron makes it difficult to remove heat from friction points. This may lead to overheating and damage of the pad structure. Other studies have shown that friction materials containing boron have a coefficient of friction higher than ordinary, commercial brake pad 0,495 . Additionally, it has been found that such materials have thermal stability up to $200^{\circ} \mathrm{C}[165,166]$.

Graphite is a material commonly used in the production of various lubricants $[167,168]$. Both natural graphite and similar materials are used, e.g. s artificial graphite, and expanded graphite [169]. Depending on the structure, contamination, and operating conditions, it may have various (but mostly positive) effects on tribological properties [169-171]. Numerous studies demonstrate initial oxidation temperatures from relatively low (approximately 180$\left.300^{\circ} \mathrm{C}[172,173]\right)$ to high, up to $700^{\circ} \mathrm{C}[174]$. Resistance to high temperatures makes graphite a favourable choice in the production of brake components for airplanes. There, brakes operate almost only in high temperatures, and therefore other properties are less important [168]. In automobile brake pads, graphite may be used as a substitute for copper because, as previously mentioned, it serves as an excellent lubricant. Graphite's lubricating properties stem from its capacity for bonding with iron oxide particles released during brake disc oxidation, which then creates a thin film on the surface of the friction pair $[175,176]$ That is why it contributes to the reduction of changes in the coefficient of friction with rising temperatures [51, 177-179], although researchers are not unanimous in this claim $[168,180]$. As for the wear rate, its value is influenced by both wt $\%$ of graphite in friction material and the operating conditions: friction speed or contact pressure [181]. Graphite is a decent heat conductor, which improves heat removal from friction points. This protects the binder, which is usually more sensitive to high temperatures [42]. At the same time, graphite is an inexpensive material. It was also observed that the use of graphite has a positive effect on braking noise reduction [171]. Leonardi $e t$ al. stated that the size of the graphite particles also influences the tribological properties. The highest value of the friction coefficient $(0.62 \pm 0.02)$ was recorded for the grains of $100 \mu \mathrm{m}$, while the lowest value of wear rate $(4.2 \pm 0.2$ $\mathrm{m}^{2} / \mathrm{N}$ ) for the smallest ones (below $40 \mu \mathrm{m}$ ) [182]. Moreover, the particle size also influences TL (thermal localisation phenomenon). The best results were obtained for samples with a graphite size below $21 \mathrm{~mm}$ [183].

Titanium is increasingly more common in the automotive industry. Its properties, which relate to the mineral's crystal structure [184], among other things, made it a suitable candidate for a brake pad material. Titanium serves well as a copper substitute, especially in high temperatures, where its lubricating properties emerge. It also balances the changes of the coefficient of friction in line with rising temperatures. This results in reduced noise during braking. Titanium's mechanical properties also contribute, by preventing the formation of film on the brake disc, due to low adhesion to iron [42]. Brake pads containing titanium are also less susceptible to brake fade $[43,185]$. Unfortunately, the material is expensive, and therefore the price of titanium brake pads is also significantly higher. The density of titanium is one of its benefits. It is a light material and therefore has a positive effect on reducing the overall weight of the braking system. Some manufacturers add titanium to their brake pads in the form of potassium titanate. The compound yields excellent results in conjunction with phenol resin and aramid pulp. This connection creates a stable film on the brake disc, which ensures improved stability of the coefficient of friction and increased

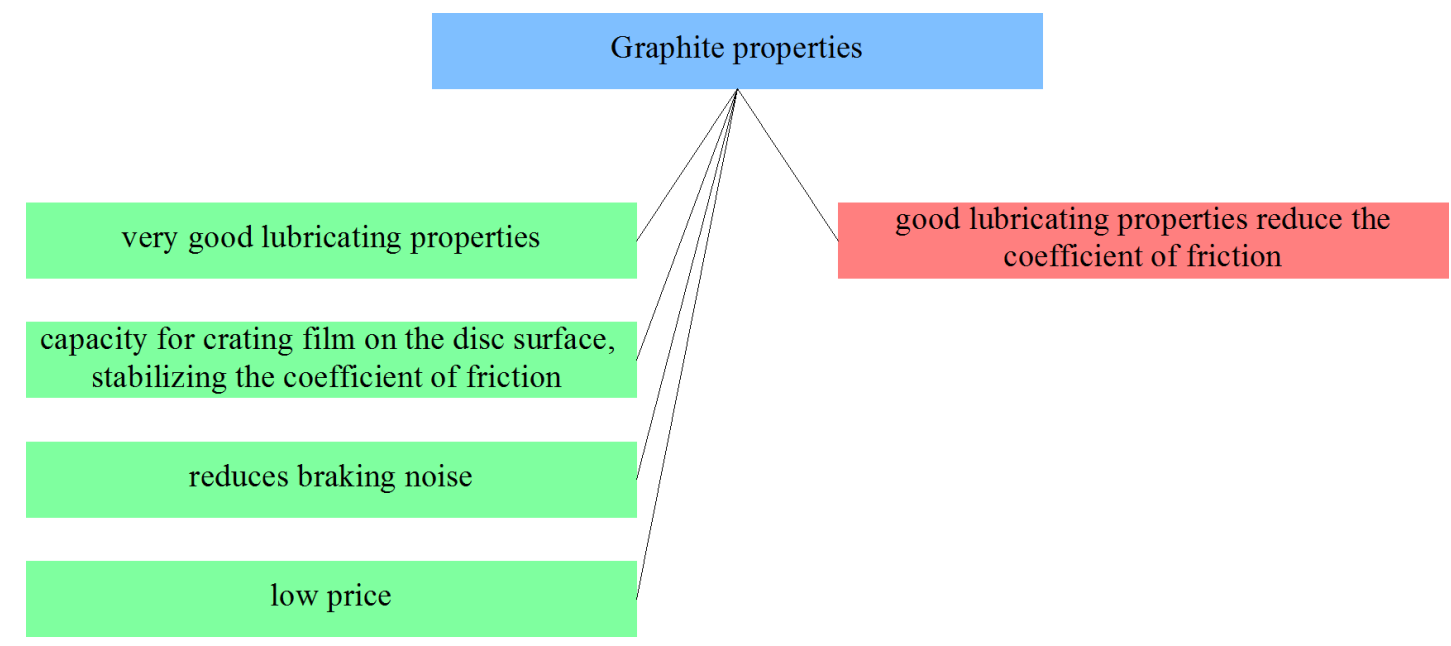

Figure 23: Selected graphite composites properties from the point of view of applicability in friction materials 


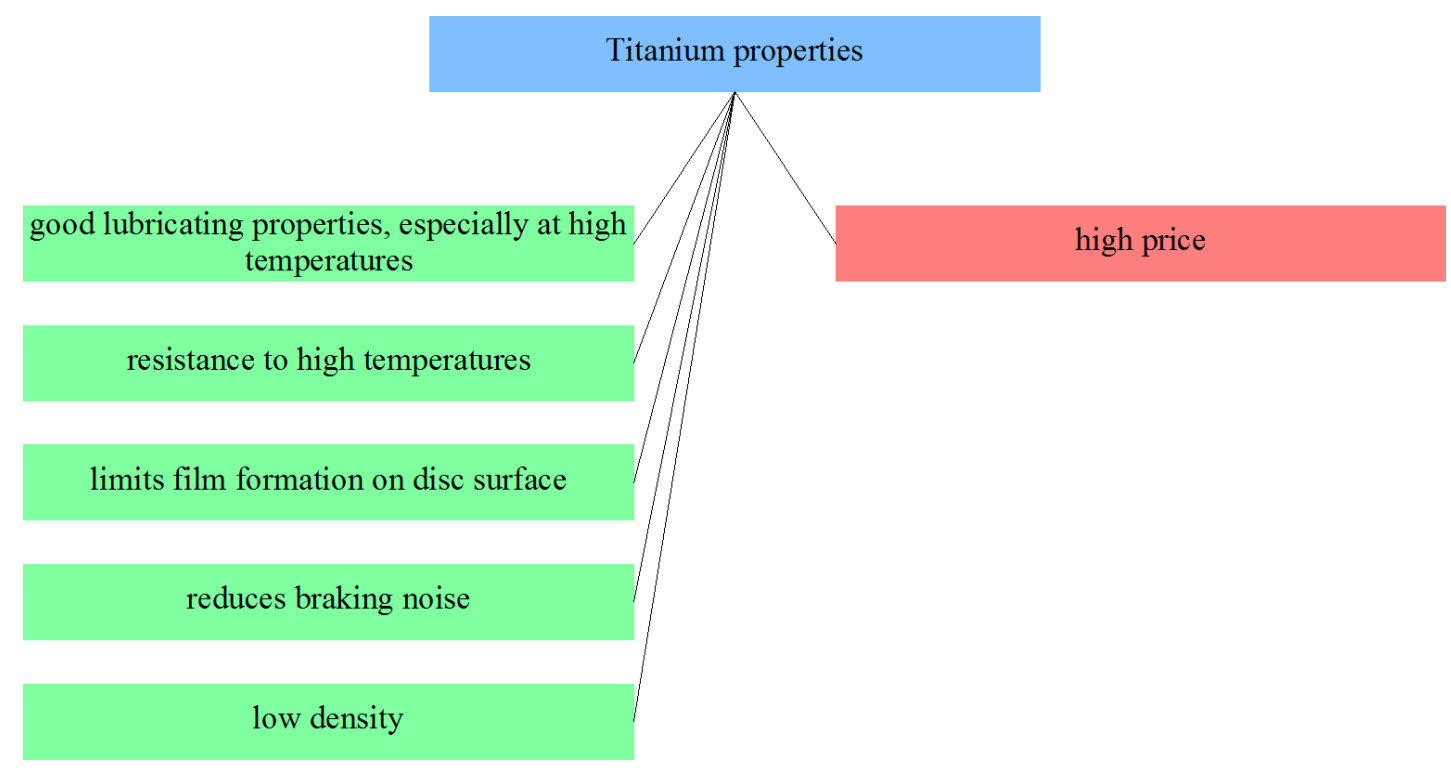

Figure 24: Selected titanium composites properties from the point of view of applicability in friction materials

wear resistance, as the ceramic material particles (potassium titanate) adhere strongly to aramid fibres. The phenomenon also has a beneficial effect on the thermal resistance of the pad [186-188].

Brass is a metal used as a friction material. Different brass fractions result in varied tribological properties of brake pads. One of the most important changes is the reduction of the coefficient of friction and a positive impact on the coefficient's changes in changing operating conditions. COF is less susceptible to changes with rising temperatures and friction speed. The pad's wear rate also changes [189]. Some research showed that with higher brass fractions, the wear rate decreases, resulting in a longer operating life of the pad $[190,191]$. Others claim that brass shortens the lifetime of the friction material, mainly when dealing with high-temperature friction [192]. That is because similarly to copper, brass improves thermal conductivity [191, 193]. Thus, more intense penetration of heat into the material takes place, which in turn accelerates the degradation of the matrix $[192,194]$. Moreover, brass demonstrates lubricating properties. That is why increasing its fraction reduces the coefficient of friction [190], which may lead to longer stopping distance. Compared to other friction materials, brass is heavy. Increased content of brass therefore results in higher density of the final product.

Cast iron is usually used in the form of crushed chips up to $1 \mathrm{~mm}$ in size. The material has a positive effect on the

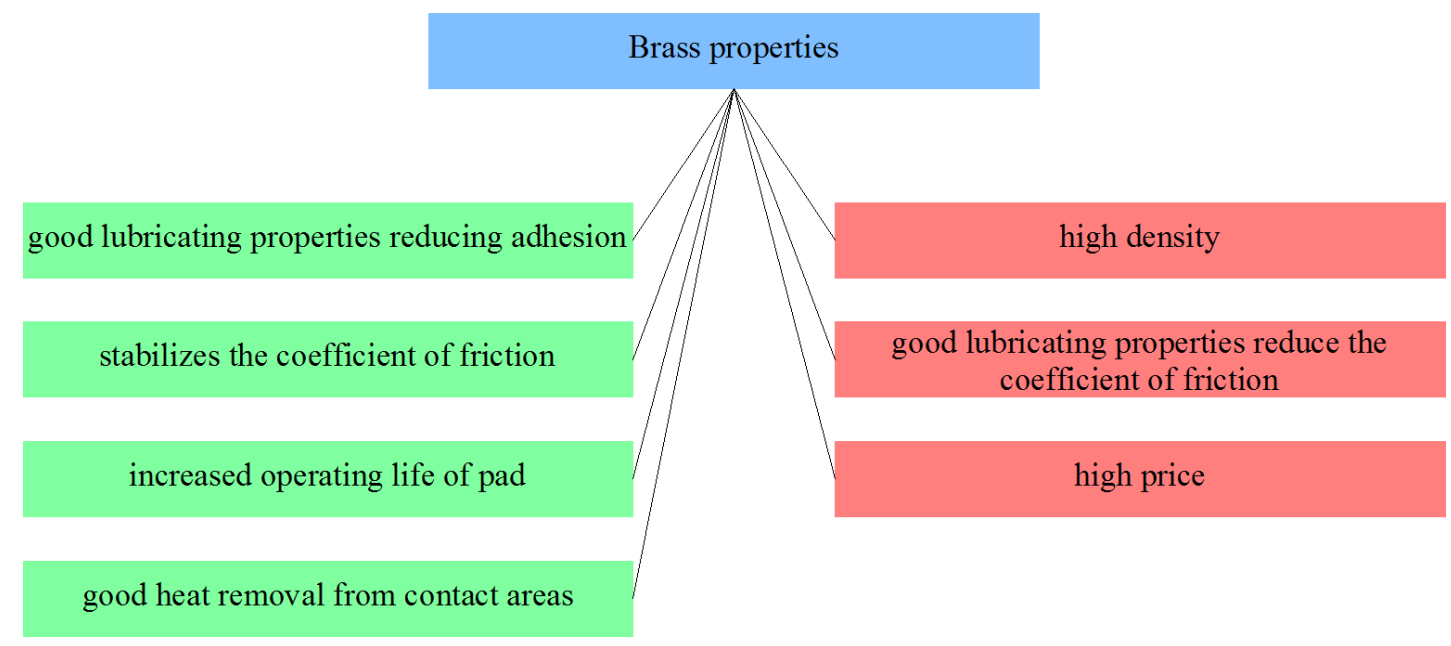

Figure 25: Selected brass composites properties from the point of view of applicability in friction materials 


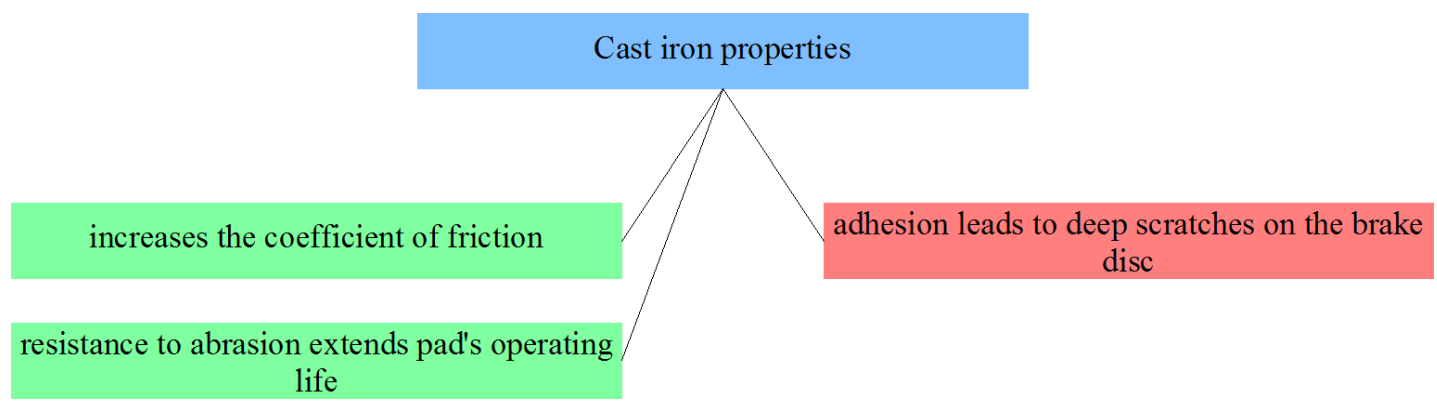

Figure 26: Selected cast iron composites properties from the point of view of applicability in friction materials

tribological properties of brake pads [31, 195]. A 2-4\% fraction of cast iron increases the coefficient of friction by adhesion on the meeting point of the friction surfaces. Cast iron is characterised by high resistance to abrasion, as it deforms under pressure to create contact areas with the brake disc in the form of ridges (other components wear more quickly by creating craters) $[41,196]$. This increases the brake pad's overall wear resistance. Different papers indicate that as friction speed and pressure increases, the coefficient of friction of brake pads with cast iron fraction may rise or fall. This is also affected by other additives, especially those with lubricating properties [158].

Steel is an alloy of iron and carbon, with a carbon fraction under $2.11 \%$. It is a friction material which increases the coefficient of friction. Additionally, through its resistance to high temperatures, it stabilizes the coefficient [51]. Steel is also a decent heat conductor, which is important in terms of the durability of the pad. Excess heat may damage the binder, but in this case it is removed to other elements of the braking system [197]. Steel is most commonly added to brake pads in the form of steel wool [198], or in the form of fibres of various shapes and sizes [199, 200]. Alterna- tively, steel powder (such as RSB 100) may be used, whose geometrical properties (significant external surface) make it possible to reduce the percentage content of steel in the final product. A similar solution might also be used to reduce copper fractions [201]. This stems from the fact that powder metallurgy technology requires the use of solid lubricants, which later serve as lubrication of the brake pad-brake disc meeting point. Appropriate manufacture technology, taking into account forging and annealing the pad, instead of the regular pressure sintering, improves the mechanical properties of the final product (also ensuring increased hardness) [202, 203]. Unfortunately, high steel fraction in the pad leads to the formation of deep scratches in the disc, which is not desired. This is the result of decent adhesive properties, creating short-lasting connections which "tear" material from the friction pair [201]. This phenomenon, however, has its benefits. It makes the connection between the fraction material and the backing plate easier, greatly facilitating the production process [202]. The properties of steel described above make brake pads with high steel content serve well in brake systems in airplanes and in any other application requiring

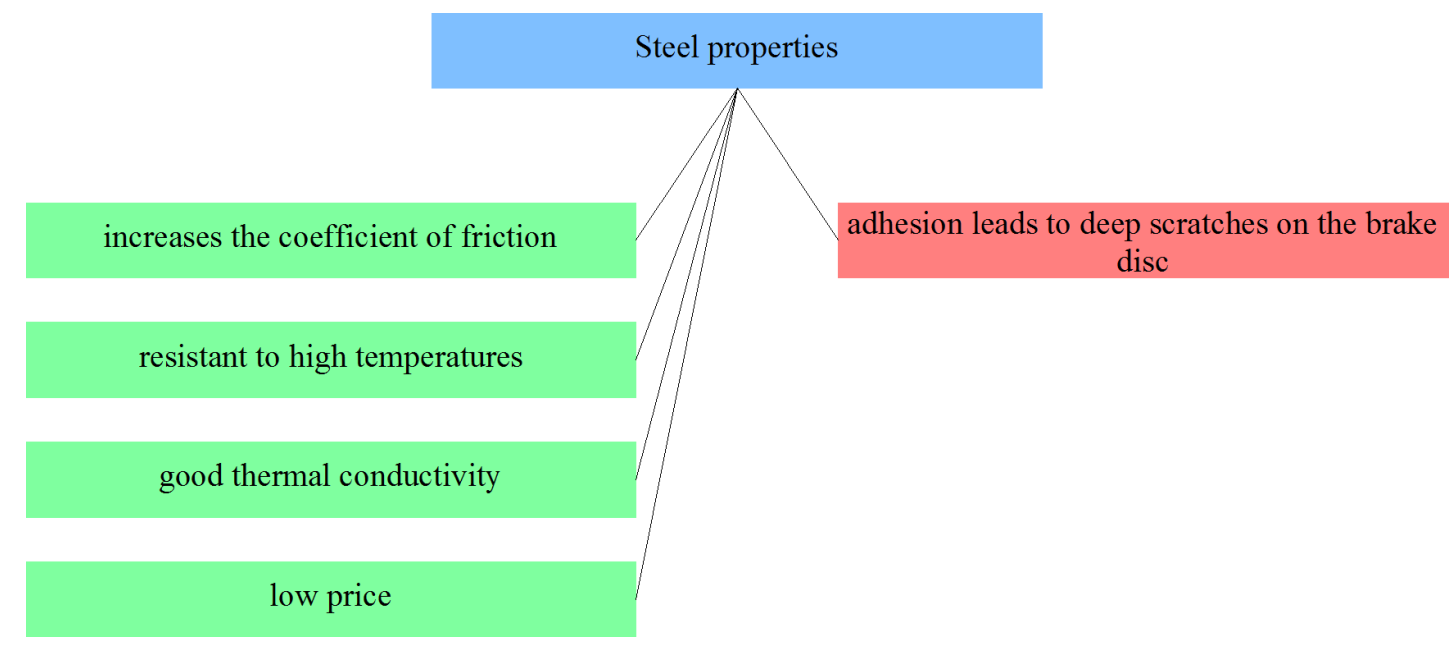

Figure 27: Selected steel composites properties from the point of view of applicability in friction materials 


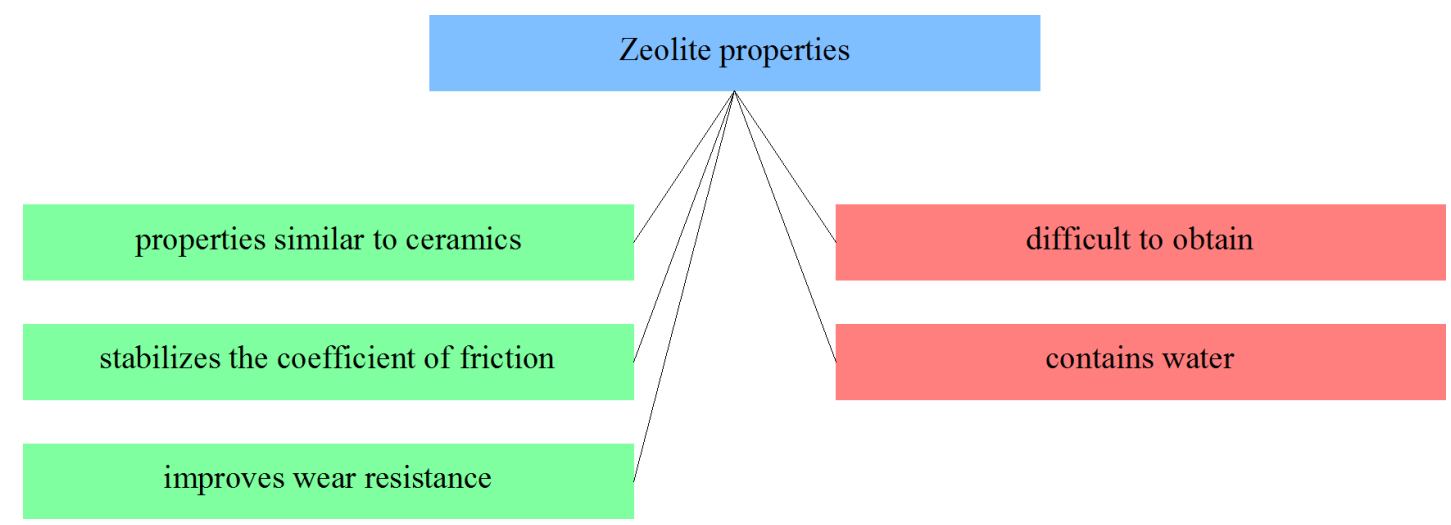

Figure 28: Selected zeolites composites properties from the point of view of applicability in friction materials

high and stable coefficient of fraction for the price of a significant wear ratio [204].

Zeolites are naturally occurring aluminosilicate minerals. Because their properties are similar to ceramics, Keskin [205] decided to use it as a component of brake pads. It was added in the form of a fine dust obtained by grinding, in proportions ranging from 5 to $35 \%$ of the pad's weight. High temperature sintering made it possible to remove the natural water content in zeolites. Research showed that zeolite may be successfully used as a friction material in brake pads. Best results were observed in $10 \%$ mineral fractions. Zeolite causes the coefficient of friction to stabilize at 0.4-0.45, and have low sensitivity to temperature changes. Similar results were obtained by Chau et al. They performed tests in the temperature range of $150-300^{\circ} \mathrm{C}$. An improvement in the anti-corrosion properties of the friction material containing zeolites has also been noted [206]. Its wear resistance also increases, extending the brake pad's operating life [205].

\section{Summary}

This work is aimed at presenting the different materials used in the production of brake pads with their main properties. Out of the multitude of different materials in use, the elaboration focused on those which are most common or the most unusual, which are still undergoing trials. Properly selecting the components and their proportions is difficult and requires extensive and time consuming (hence, expensive) research, which only a handful of producers can afford. The right composition and proportions ensure not only that the stopping force is appropriate and constant, but also increase the comfort by decreasing the abrasive wear rate and reducing the noise generated by friction $[207,208]$.
It is important for researchers and research institutes around the world to conduct studies aimed at improving our understanding of the complexity of tribological phenomena occurring in the friction pair, which could lead to developing new and innovative brake pad production technologies or compositions, such as utilizing industrial or agro-food waste. Bearing in mind the current trends in environmental protection, the development of friction materials should be aimed at reducing the use of artificial components. It is important that wear particle emissions are degraded without releasing toxic compounds. The facts presented in the manuscript seem to confirm this trend. Zeolites, banana peels, periwinkle shells or coconut fragments that appear more and more often in friction materials give hope to reduce the level of environmental pollution by vehicles. This is the only possible way as there is no physical possibility of "picking up" the particles of the brake pads and discs that separate during braking and recycling or utilization of them.

Acknowledgement: This research was financed through subsidy of the Ministry of Science and Higher Education of Poland for the discipline of mechanical engineering at the Faculty of Mechanical Engineering Bialystok University of Technology WZ/WM-IIM/4/2020.

\section{References}

[1] Jaafar TR, Selamat MS, Kasiran R. Selection of Best Formulation for Semi-Metallic Brake Friction Materials Development. Powder Metallurgy. Shanghai, China: InTech; 2012.

[2] Darius GS, Berhan MN, David NV, Shahrul AA, Zaki MB. Characterization of brake pad friction materials. In: Brebbia CA, Alberto A (eds) Computational Methods and Experiments in Materials Characterization II. Southhampton: WIT Press; 2005, p.43-50. 
[3] Borawska E, Borawski A. Influence of the initial speed of the agricultural tractor on the brakes heating process during emergency braking. Heat Transf Res. 2020;51(10):967-74.

[4] Chandgude SB, Ganiger SG. Review on development of composite material for disc brake pad [JETIR]. J Emerg Technol Innov Res. 2016;3(5):63-5.

[5] Blau PJ, McLaughlin JC. Effect of water films and sliding speed on the frictional behavior of truck disc brake materials. Int J Trichology. 2003;36:709-15.

[6] Borawski A. Suggested research method for testing selected tribological properties of friction components in vehicle braking systems. Acta Mechanica et Automatica. 2016;10(3):223-6.

[7] Kulikowski K, Szpica D. Determination of directional stiffnesses of vehicels' tires under a static load operation. Maintenance and Reliability. 2014;16(1):66-72.

[8] Borawski A, Szpica D, Mieczkowski G. Verification tests of frictional heat modelling results. Mechanika. 2020;26(5):260-4.

[9] Maluf O, Angeloni M, Milan MT, Spinelli D, Waldek W, Filho B. Development of materials for automotive disc brakes. Minerva. 2007;4(2):149-58.

[10] Schmidt DL, Davidson KE, Theibert LS. Unique applications of carbon/carbon composite materials, part 1. Sampe J.1999;35(3):2739.

[11] Singh SP. Analysis of brake-pad friction material formulation. Journal of Engineering Research and Science. 2015;2(8):6-13.

[12] Borawski A. Simulation Study of the Process of Friction in the Working Elements of a Car Braking System at Different Degrees of Wear. Acta Mechanica et Automatica. 2018;12(3):221-6.

[13] Neharkar SP, Patil RJ, Sonawane PR. Study of friction and wear for optimization of disc break material for reduction of brake sound. International journal of research in aeronautical and mechanical engineering. 2014;2(6):137-44.

[14] Bevilacqua M, Babutskyi A, Chrysanthou A. A review of the catalytic oxidation of carbon-carbon composite aircraft brakes. Carbon. 2015;95:861-9.

[15] Awasthi S, Wood JL. Carbon/Carbon Composite Materials for Aircraft Brakes. In: Wachtman JB, editor. Ceramic Engineering and Science Proceedings. USA: Wiley; 1988.

[16] Shojaei A, Fahimian M, Derakhshandeh B. Thermally conductive rubber-based composite friction materials for railroad brakes - Thermal conduction characteristics. Compos Sci Technol. 2007;67(13):2665-74.

[17] Bijwe J. Composites as friction materials: recent developments in non-asbestos fiber reinforced friction materials-a review. Polym Compos. 2014;18(3):378-96.

[18] Venugopal S, Karikalan L. A review paper on aluminium-alumina arrangement of composite materials in automotive brakes. Mater Today Proc. 2020;21(1):320-3.

[19] Kryachek VM. Friction composites: traditions and new solutions (review). I. Powder materials. Powder Metall Met Ceramics. 2004;43(11-12):581-92.

[20] Kryachek VM. Friction Composites: Traditions and New Solutions (Review). Part 2. Composite Materials. Powder Metall Met Ceramics. 2005;44(1-2):5-16.

[21] Naresh Kumar K, Suman KN. Review of brake friction materials for future development. Journal of Mechanical and Mechanics Engineering. 2017;3(2):1-2.

[22] Liu Y, Bao J, Hu D, Ge S, Yin Y, Liu T. A Review on the Research Progress of Nano Organic Friction Materials. Recent Pat Nanotechnol. 2016;10(1):11-9.
[23] Kato K. Wear in relation to friction - a review. Wear. 2000; 241(2):151-7.

[24] Chan D, Stachowiak GW. Review of automotive brake friction materials. Journal automobile engineering Part D. 2004;218:95366. https://doi.org/10.1243/0954407041856773.

[25] Harper GA. Review of Brakes and Friction Materials. The History and Development of the Technologies. London: Mechanical Engineering Publications; 1997.

[26] Zhu T, Gao C. The development and prospect of friction materials. Journal of Fuzhou University. 2001;6:52-5.

[27] He D, Wang C, Wang H. Investigation Status of Friction Materials for Automobiles. Engineering Plastics Application. 2002;2:54-7.

[28] Xiao X, Yin Y, Bao J, Lu L, Feng X. Review on the friction and wear of brake materials. Adv Mech Eng. 2016;8(5):1-10.

[29] Blau PJ. Compositions, Functions and Testing of Friction Brake Materials and Their Additives. Tennessee: Oak Ridge National Laboratory Report, US Department of Energy, Tenessee; 2001 Report no.: ORNLITM-2001/64, Sponsored by the Department of Energy.

[30] Borawski A. Common methods in analysing the tribological properties of brake pads and discs - a review. Acta Mechanica et Automatica. 2019;13(3):189-99.

[31] Nagesh SN, Siddaraju C, Prakash SV, Ramesh MR. Characterization of brake pads by variation in composition of friction materials. Procedia Materials Science. 2014;5:295-302.

[32] Nicholson G. Facts about friction: 100 years of brake linings and clutch facings. 2nd ed. Croydon: P\&W Price Enterprises Inc.; 1995.

[33] Patel SK, Jain AK. Experimental study of brake lining materials with different manufacturing parameters [IJETT]. International Journal of Engineering Trends and Technology. 2014;7(4):192-7.

[34] Gujrathi TV, Damale AV. A review on friction materials of automobile disc brake pad. International Journal of Engineering [ARDIJEET]. Educ Technol. 2015;3(2):1-4.

[35] Aza CA. Composites in Automotive Applications: Review on brake pads and discs. 2014 [cited 2017 June 21] Available from: www.bristol.ac.uk/engineering/media/accis/cdt/news/aza.pdf

[36] Bijwe J. Composites as friction materials: Recent Developments in Non- Asbestos Fibre reinforced Friction Materials. Polym Compos. 1997;18(3):378-95.

[37] Lemen RA. Asbestos in brakes: exposure and risk of disease. Am J Ind Med. 2004 Mar;45(3):229-37.

[38] Ikpambese KK, Gundu DT, Tuleun LT. Evaluation of palm kernel fibers (PKFs) for production of asbestos-free automotive brake pads. Journal of King Saud University - Eng Sci. 2016;28:110-8.

[39] Ganguly A, George R. Asbestos free friction composition for brake linings. Bull Mater Sci. 2008;31(1):19-22.

[40] Kim YC, Cho MH, Kim SJ, Jang H. The effect of phenolic resin, potassium titanate, and CNSL on the tribological properties of brake friction materials. Wear. 2008;264(3-4):204-10.

[41] Eriksson M, Lord J, Jacobson S. Wear and contact conditions of brake pads: dynamical in situ studies of pad on glass. Wear. 2001;249(3-4):272-8.

[42] Mitsumoto M. Copper free brake pads with stable friction coefficient. Japan: Hitachi Chemical Technical Report; 2017 Mar. Report No.59. Sponsored by the Social Infrastructure-related Materials Development Center, R\&D Headquarters.

[43] Kim SJ, Cho MH, Cho KH, Jang H. Complementary effects of solid lubricants in the automotive brake lining. Tribol Int. 2007;40(1):15-20. 
[44] Gudmand-Hoyer L, Bach A, Nielsen GT, Morgen P. Tribological properties of automotive disc brakes with solid lubricants. Wear. 1999;232(2):168-75.

[45] Szpica D. New Leiderman-Khlystov Coefficients for Estimating Engine Full Load Characteristics and Performance. Chin J Mech Eng. 2019;32(1):95.

[46] Dmitriev Al, Osterle W, Kloss H. About the influence of automotive brake pad composition on frictional performance. Results of nano-scale modeling. Nanosystems: physics, chemistry, mathematics. 2011;2(2):58-64.

[47] Franck RR. Bast and other plant fibres. Cambridge, UK: Woodhead publishing; 2005. https://doi.org/10.1533/978184569 0618.

[48] Crosa G, Baumvol IJ. Tribology of composites used as friction materials. In: Friedrich K, editor. Advances in composite Tribology. Germany: Elsevier; 1993. pp. 583-626.

[49] Loken HY. Asbestos free brakes and dry clut chesreinforced with Kevlar aramid fiber. SAE paper 1980-800667 (1980).

[50] Mieczkowski G. Stress fields at the tip of a sharp inclusion on the interface of a bimaterial. Mech Compos Mater. 2016;52(5):60110.

[51] Incesu A, Korkmaz K, Cetintas 00, Kubuc 0, Korkmaz M, Karanfil G. Design of comosite brake pads for metro with statistical approach. In: 2. Uluslar arası Raylı Sistemler Mühendisliği Sempozyumu (ISERSE'13); 2013 Oct 9-11; Karabük, Turkey.

[52] Dureja N, Bijwe NJ, Gurunath PV. Role of type and amount of resin on performance behavior of non-asbestos organic (NAO) friction materials. Journal of reinforced plastic and composites. 2009;28(4):489-97.

[53] Mieczkowski G, Borawski A, Szpica D. Static Electromechanical Characteristic of a Three-Layer Circular Piezoelectric Transducer. Sensors (Basel). 2019 Dec;20(1):1-14.

[54] Bijwe J, Nidhi N, Satapathy BK. Influence of amount of resin on fade and recovery behavior of non- asbestos organic (NAO) friction material. Int J Water. 2006;23(3):215-22.

[55] Bijwe NJ, Majumdar N. Influence of amount and modification of resin on fade and recovery behavior of non-asbestos organic (NAO) friction materials. Tribol Lett. 2006;23(3):215-22.

[56] Bijwe NJ. NBR-modified resin in fade and recovery module in nonasbestos organic (NAO) friction materials. Tribol Lett. 2007;27(2):189-96.

[57] Yanar H, Ayar HH, Demirtas M, Purcek G. Effect of resin content on tribological behavior of brake pad composite material. Ind Lubr Tribol. 2018;72(2):195-202.

[58] Mieczkowski G. Criterion for crack initiation from notch located at the interface of bi-material structure. Eksploatacja i Niezawodność. 2019;21(2):301-10.

[59] Menapace C, Leonardi M, Secchi M, Bonfanti A, Gialanella S, Straffelini G. Thermal behavior of a phenolic resin for brake pad manufacturing. J Therm Anal Calorim. 2019;137(3):759-66.

[60] Bijwe J. Composites as friction material: recent development in non-asbestos fiber reinforced friction material- a review. Polym Compos. 1997;18(3):378-96.

[61] Cardona F, Kin-Tak AL, Fedrigo J. Novel phenolic resins with improved mechanical and toughness properties. J Appl Polym Sci. 2012;123(4):2131-9.

[62] Komori T, Miyake S, Senoo Y. Brake friction material. United States patent 4954536. 1990.

[63] Kakegawa H, Yasuda T, Wang X. Binder Composition for Friction Materials, and Friction Materials. United States patent 5889081
1999.

[64] Wu J, Jia Z, Yannan YH, Yu ZQ. Investigation on thermal stability and tribological properties of $\mathrm{ZrB}_{2}$ particles filling cyanate ester resin composites by experiments and numerical simulation. Polym Eng Sci. 2018;59(3):602-7.

[65] Bajpai A, Saxena P, Kunze K. Tribo-Mechanical Characterization of Carbon Fiber-Reinforced Cyanate Ester Resins Modified With Fillers. Polymers (Basel). 2020 Jul;12(8):1725.

[66] Shivakumar K, Abali F, Sadler R. Development of cyanate ester based carbon/carbon composites. ICCM-12: Proceedings of the 1999 International Conference on Composite Material; 1999 Jul 5-9; Paris, France.

[67] McCormick FB, Drath DJ, Gordisher I, Kropp AM, Palazzotto MC, Sahyun RV. Energy-Curable cyannate/ethylenically unsaturated compositions. United States patent US6069219A. 2000.

[68] Hamerton I. Chemistry and Technology of Cyanate Ester Resins. UK: Springer Science \& Business Media; 2012.

[69] Avallone EA, Baumeister T, Sadegh AM. Marks Handbook for Mechanical Engineers. 11th ed. New York: McGraw-Hill; 2007.

[70] Agunsoye JO, Bello SA, Bamigbaiye AA, Akinboye IO. Recycled ceramic composite for automobile brake pad application. Journal of Research in Physics. 2018;1(39):35-46.

[71] Szpica D. Modelling of the operation of a Dual Mass Flywheel (DMF) for different engine-related distortions. Math Comput Model Dyn Syst. 2018;24(6):643-60.

[72] Szpica D. Simplified numerical simulation as the base for throttle flow characteristics designation. Mechanika. 2015;21(2):129-33.

[73] Szpica D, Piwnik J, Sidorowicz M. The motion storage characteristics as the indicator of stability of internal combustion engine receiver cooperation. Mechanika. 2014;20(1):108-12.

[74] Mieczkowski G. Static Electromechanical Characteristics of Piezoelectric Converters with various Thickness and Length of Piezoelectric Layers. Acta Mech Autom. 2019;13(1):30-6.

[75] Mieczkowski G. Optimization and prediction of durability and utility features of three-layer piezoelectric transducers. Mechanika. 2018;24(3):335-42.

[76] Szpica D. Comparative analysis of low pressure gas-phase injector's characteristics. Flow Meas Instrum. 2017;58:74-86.

[77] Kamble M, Shakfeh T, Moheimani R, Dalir H. Optimization of a Composite Monocoque Chassis for Structural Performance: A Comprehensive Approach. J Fail Anal Prev. 2019;19(5):1252-63.

[78] Li W, Yang X, Wang S, Xiao J, Hou Q. Comprehensive Analysis on the Performance and Material of Automobile Brake Discs. Metals (Basel). 2020;10(3):377.

[79] Saravanan V, Thyla PR, Balakrishnan SR. A low cost, light weight cenosphere-aluminium composite for brake disc application. Bull Mater Sci. 2016;39(1):299-305.

[80] Ismaila S, Jatau JS, Bawa MA. Particulate Reinforced Aluminium Alloy Matrix Composite Brake Rotor - A Review of the Mechanical and Wear Behaviours. Journal of Scientific and Engineering Research. 2019;6(7):29-40.

[81] Sadagopan P, Natarajan HK, Praven KJ. Study of silicon carbidereinforced aluminum matrix composite brake rotor for motorcycle application. Int J Adv Manuf Technol. 2018;94(1-4):1461-75.

[82] Sivananthan R, Tharun K, Lokesh G, Vijayaganapathy D. Experimentation on composite brake pads with aluminum reinforcement of SiC and Flyash. Int J Pure Appl Math. 2018;118(24):1-11.

[83] Purkar AV, Deore ER. Wear behavior of Aluminium Metal Matrix Composite with Silicon Carbide used for Brake Pads under Dry Friction Condition. International Advanced Research Journal in 
Science. Engineering and Technology. 2016;3(6):72-6.

[84] Szpica D. Validation of indirect methods used in the operational assessment of LPG vapor phase pulse injectors. Measurement. 2018;118:253-61.

[85] Bracamonte L, Withers J, Smith T. Lightweight, Wear Resistant, High Thermal Conductivity Metal Matrix Composite Brake Rotors. SAE Technical Paper, ATS-MER, LLC, Michigan, USA, 2018.

[86] Peng T, Yan Q, Zhang X. Stability of Metal Matrix Composite Pads During High-Speed Braking. Tribol Lett. 2018;66(2):1-13.

[87] Nturanabo F, Masu L, Kirabira JB. Novel Applications of Aluminium Metal Matrix Composites. In: Cooke K, editor. Aluminium Alloys and Composites. London: IntechOpen; 2020. https://doi.org/10.5772/intechopen.86225.

[88] Afshari M, Doetze J, Lee K, Bogle M. High Performance Fibers Based on Rigid and Flexible Polymers. Polym Rev (Phila Pa). 2008;48(2):230-74.

[89] Szpica D. Coefficient of Engine Flexibility as a Basis for the Assessment of Vehicle Tractive Performance. Chin J Mech Eng. 2019;32(1):39.

[90] Lemstra PJ. Modification and Blending of Synthetic and Natural Macromolecules. Kluwer. Netherlands: Kluwer Academic Publishers; 2004.

[91] Briscoe BJ, Tweedale PJ. Aramid fibre friction: A replacement for asbestos in high friction materials. In: Tribology of composite materials; 1990 May 1-3; Oak Ridge, USA.

[92] Bhane AB, Kharde RR, Honrao VP. Investigation of Tribological Properties for Brake Pad Material: A Review. Int J Emerg Technol Adv Eng. 2008;4(9):530-2.

[93] Kato T, Magario A. The wear of aramid fibre reinforced brake pads: the role of aramid fibres. Tribol Trans. 1994;37(3):559-65.

[94] Kim SJ, Jang H. Friction and wear of friction materials containing two different phenolic resins reinforced with aramid pulp. Tribol Int. 2000;33(7):477-84.

[95] Aranganathan N, Mahale V, Bijwe J. Effects of aramid fiber concentration on the friction and wear characteristics of non-asbestos organic friction composites using standardized braking tests. Wear. 2016;354-355:69-77.

[96] Ahmadijokaniab F, Shojaeia A, Dordanihaghighi S. Effects of hybrid carbon-aramid fiber on performance of non-asbestos organic brake friction composites. Wear. 2020;452-453:203280.

[97] Gopal P, Dharani LR, Frank D. Hybrid phenolic friction composites containing Kevlar pulp: part II-Wear surface characterization. Wear. 1996;193(2):180-5.

[98] Sampath V. Studies on mechanical, friction, and wear characteristics of Kevlar and glass fiber-reinforced friction materials. Mater Manuf Process. 2006;21(1):47-57.

[99] Yu LG, Yang SR. Investigation of the transfer film characteristics and tribochemical change of Kevlar fibres reinforced polyphenylene-sulfide composites in sliding against a tool steel counterface. Thin Solid Films. 2002;413(1-2):98-103.

[100] Kim SH, Jang H. Friction and vibration of brake friction materials reinforced with chopped glass fibers. Tribol Lett. 2013;52(2):3419.

[101] Gweon JH, Joo BS, Jang H. The effect of short glass fiber dispersion on the friction and vibration of brake friction materials. Wear. 2016;362-363:61-7.

[102] Bahadur S, Zheng Y. Mechanical and tribological behavior of polyester reinforced with short glass fibers. Wear. 1990; 137(2):251-66.
[103] Parandaman P, Jayaraman M, Ramasamy K. Mechanical Performance of Coir and Glass Fibre Reinforced Hybrid composite materials for Automotive Brake Pad. Int J Appl Eng Res. 2015;10(32):23981-8.

[104] Gopal P, Dharani LR, Frank DB. Fade and wear characteristics of a glass fiber reinforced phenolic friction materials. Wear. 1994;174(1-2):119-27.

[105] Verma AP, Vishwanath B, Rao CV. Effect of resin modification on friction and wear of glass phenolic composite. Wear. 1996;93(2):193-8.

[106] Xin X, Xu CG, Qing LF. Friction properties of sisal fibre reinforced resin brake composites. Wear. 2007;262(5-6):736-41.

[107] Bijwe J. Composites as friction materials: recent developments in non-asbestos fiber reinforced friction materials - a review. Polym Compos. 1997;18(3):378-96.

[108] Gweon JH, Soo B, Jang JH. The effect of short glass fiber dispersion on the friction and vibration of brake friction materials. Wear. 2016;362-363:61-7.

[109] Nemec L. Engineering and chemistry of the glass-melting process. Pure Appl Chem. 2002;74(11):2119-29.

[110] Olupona JA, Abodunwa JA, Fayoyin FK. Response of laying hens to graded levels of cocoa bean shells. Proceedings of 28th Ann. Conf., Nig. Soc. Anim. Prod.; 2003 Mar 16-20.

[111] Dan-Asabe B, Madakson PB, Manji J. Material Selection and Production of a Cold-Worked Composite Brake Pad. World J of Engineering and Pure and Applied Sci. 2012;2(3):92-7.

[112] Olabisi Al, Adam AN, Okechukwu OM. Development and Assessment of Composite Brake Pad Using Pulverized Cocoa Beans Shells Filler. Int J Mater Sci Appl. 2016;5(2):66-78.

[113] Okoroigwe EC, Saffron CM, Kamdem PD. Characterization of palm kernel shell for materials reinforcement and water treatment. Journal of Chemical Engineering and Materials Science. 2014;5(1):1-6.

[114] Achebe $\mathrm{CH}$, Chukwuneke JL, Anene FA. A retrofit for asbestosbased brake pad employing palm kernel fiber as the base filler material. Proceedings of the Institution of Mechanical Engineers, Part L: Journal of Materials: Design and Applications. 2018; 233(9):1906-13.

[115] Fono-Tamo RS, Koya OA. Evaluation of Mechanical Characteristics of Friction Lining from Agricultural Waste. International Journal of Advancements in Research \& Technology. 2013;2(11):1-5.

[116] bhadode AO, Dagwa IM. Development of asbestos-free friction lining material from palm kernel shell. J Braz Soc Mech Sci Eng. 2008;30(2):166-73.

[117] Deepika K, Bhaskar Reddy C, Ramana Reddy D. Fabrication and Performance Evaluation of a Composite Material for Wear Resistance Application [IJESIT]. International Journal of Engineering Science and Innovative Technology. 2013;2(6):66-71.

[118] Mgbemena CO, Mgbemena CE, Okwu MO. Thermal stability of pulverized palm kernel shell (PKS) based friction lining material locally developed from spent waste. ChemXpress. 2014;5(4):11522.

[119] Elakhame ZU, Alhassan OA, Samuel AE. Development and Production of Brake Pads from Palm Kernel Shell Composites. Int J Sci Eng Res. 2014;5(10):735-44.

[120] Tchobanoglous T, Theisen H, Vigil S. Integrated Solid Waste Management-Engineering Principles and Management Issues. New York: McGraw-Hill Book Co.; 1993.

[121] Zhang P, Whistler RL. BeMiller JN, Hamaker BR. Banana starch: Production, physicochemical properties, and digestibility. Car- 
bohydr Polym. 2005;59:443-58.

[122] Someya S, Yoshiki Y, Okubo K. Antioxidant compounds from bananas (Musa Cavendish). Food Chem. 2002;79(3):351-4.

[123] Lee EH, Jung H. Development of banana peel jelly and its antioxidant and textural properties. J Food Sci. 2010;•••:449-55.

[124] Happi Emaga T, Ronkart SN, Robert C, Wathelet B, Paquot M. Characterisation of pectins extracted from banana peels (Musa AAA) under different conditions using an experimental design. Food Chem. 2008 May;108(2):463-71.

[125] Idris UD, Aigbodion VS, Abubakar IJ, Nwoye Cl. Eco-friendly asbestos free brake-pad: Using banana peels. Journal of King Saud University -. Eng Sci. 2015;27(2):185-92.

[126] Masrat B, Sheikh SS, Owais B. Friction and wear behavior of disc brake pad material using banana peel powder. Int J Res Eng Technol. 2015;4(2):650-9.

[127] Aku SY, Yawas DS, Madakson PB. Characterization of periwinkle shell as asbestos-free brake pad materials. Pac J Sci Technol. 2012;13(2):57-63.

[128] Aigbodion VS, Agunsoye JO. Bagasse (Sugarcane Waste): NonAsbestos Free Brake Pad Materials. Berlin, Germany: LAP Lambert Academic Publishing; 2010.

[129] Elakhame ZU, Olotu OO, Abiodun YO, Akubueze EU, Akinsanya 00, Kaffo PO, et al. Production of asbestos free brake pad using periwinkle shell as filler material. Int J Sci Eng Res. 2017;8(6):1728-35.

[130] Amaren SG, Yawas DS, Aku SY. Effect of periwinkles shell particle size on the wear behavior of asbestos free brake pad. Results Phys. 2013;3:109-14.

[131] Szpica D, Czaban J, Banaszuk P, Weresa E. The diesel and the vegetable oil properties assessment in terms of pumping capability and cooperation with internal combustion engine fuelling system. Acta Mechanica et Automatica. 2015;9(1):14-8.

[132] Langhofa N, Rabensteinb M, Rosenlöcher J, Hackenschmidt R, Krenkel W, Rieg F. Full-ceramic brake systems for high performance friction applications. J Eur Ceram Soc. 2016;36(15):382332.

[133] Krenkel W, Langhof N. Ceramic matrix composites for high performance friction applications. Proceedings of IV Advanced Ceramics and Applications Conference; 2014 Sep 29 - Oct 1; Belgrade, Serbia. https://doi.org/10.2991/978-94-6239-213-7_2.

[134] Renz R, Seifert G, Krenkel W. Integration of CMC brake discs in automotive brake systems. Int J Appl Ceram Technol. 2012;9(4):712-24.

[135] Li Z, Xiao P, Xiong X, Huang B. Manufacture and properties of carbon fibre-reinforced $\mathrm{C} / \mathrm{SiC}$ dual matrix composites. $\mathrm{N}$ Carbon Mater. 2010;25(3):225-31.

[136] Wojciechowski A, Sobczak J. Alternative composite material solution in the frictional connections. Journal of KONES. 2003;10(34):379-89.

[137] Telang A, Rehman A, Dixit G, Das S. Effect of reinforcement and heat treatment on the friction performance of Al Si alloy and brake pad pair. Arch Appl Sci Res. 2010;2(4):95-102.

[138] Sugözü B, Dağhan B. Effect of $\mathrm{BaSO}_{4}$ on Tribological Properties of Brake Friction Materials. Int J Innov Res Sci Eng Technol. 2016;5(12):30-5.

[139] El Soeudy RI, El-Butch AM, Fahim AF, Kamal AM. Influence of barium sulfate on the physical, mechanical, tribological properties and dynamic behavior of a brake lining. ICSV 17: The $17^{\text {th }}$ International Congress on Sound \& Vibration; 2010 Jul 18-22; Cairo, Egypt.
[140] Menapace C, Leonardi M, Matějka V, Gialanella S, Straffelini G. Dry sliding behavior and friction layer formation in copper-free barite containing friction materials. Wear. 2018;398-399:191200.

[141] Chudek M, Hyncar J. Węgiel brunatny - utylizacja surowców towarzyszących i odpadów elektrownianych [Lignite - recycling of accompanying raw materials and waste from the power plants]Gliwice: Wydawnictwo Politechniki Śląskiej; 1999.

[142] Malhotra VM, Valimbe PS, Wright MA. Effects of fly ash and bottom ash on the frictional behavior of composites. Fuel. 2002;81(2):235-44.

[143] Vijay R, Rajesh Kumar S, Satish V, Subramaniam L. Development and testing of asbestos free brake pad material. International Journal of Manufacturing Science and Engineering. 2011;2(2):5763.

[144] Natarajan MP, Rajmohan B, Devarajulu S. Effect of ingredients on mechanical and tribological characteristics of different brake liner materials. Int. J. Mech. Eng. \& Rob. Res. 2012;1(2):135-57.

[145] Nandan DA, Bharat S, Tomar B, Satapathy BK. Satapathy, Evaluation of Flyash-Filled and Aramid Fibre Reinforced Hybrid Polymer Matrix Composites (PMC) for Friction Braking Applications. Mater Des. 2009;30(10):4369-76.

[146] Chugh YP, Filip P, Mohanty S, Hee K. A collaborative program for development of frictional materials using industrial wastes. Progress Through Partnership: International Conference on Engineering Education and Research; 2004 Jun 27-30; Ostrava, Czech Republic.

[147] Sugözü B. Tribological properties of brake friction materials containing fly ash. Ind Lubr Tribol. 2018;70(5):902-6.

[148] Choosri S, Sombatsompop M, Wimolmala E, Thongsang S. Potential use of fly ash and bagasse ash as secondary abrasives in phenolic composites for eco-friendly brake pads applications. Proceedings of the Institution of Mechanical Engineers, Part D. Journal of Automobile Engineering Institution of Mechanical Engineers. 2018;233(5):1296-305.

[149] Samrat M, Chugh YP. Development of Flyash-Based Automotive Brake Lining. Tribol Int. 2007;40(7):1217-24.

[150] Marewad DS, Singh GP, Adivarekar RV. Asbestos free brake pad using Micro cellulose fibre for automotive industry. International Journal of Advance Research. Ideas and Innovations in Technology. 2018;4(4):685-90.

[151] Kovach JA, Grambo RE. Performance characteristics of a non asbestos cellulose fibre composite friction material. SAE paper 800979, 1980.

[152] Kumar M, Bijwe J. Role of different metallic fillers in nonasbestos organic (NAO) friction composites for controlling sensitivity of coefficient of friction to load and speed. Tribol Int. 2010;43(5-6):965-74.

[153] Borawski A, Borawska E, Obidziński S, Tarasiuk W. Effect of the chemical composition of the friction material used in brakes on its physicochemical properties. Laboratory tests. Przem Chem. 2020;99(5):1000-4.

[154] Borawski A, Mieczkowski G, Szpica D. Simulation tests of peripheral friction brake used in agricultural machinery shafts. Proceedings of Engineering for Rural Development: 19th International Scientific Conference; 2020 May 20-22; Jelgava, Latvia. Latvia University of Life Sciences and Technologies; 2020. p. 494-502.

[155] El-Tayeb NS, Liew KW. On the dry and wet sliding performance of potentially new frictional brake pad materials for automotive industry. Wear. 2009;266(1-2):275-87. 
[156] Yi G, Yan F. Mechanical and tribological properties of phenolic resin-based friction composites filled with several inorganic fillers. Wear. 2007;262(1-2):121-9.

[157] Osterle W, Prietzel C, Kloß H, Dmitriev Al. On the role of copper in brake friction materials. Tribol Int. 2010;43(12):2317-26.

[158] Surojo E, Jamasri, Malau V, Ilman MN. Investigation of friction behaviors of brake shoe materials using metallic filter. Tribology in industry. 2015;37(4):473-81.

[159] Sharma S, Bijwe J, Kumar M. Comparison between nano-and micro-sized copper particles as fillers in NAO friction materials. Nanomaterials and Nanotechnology. 2013;3:3-12.

[160] Shorowordi KM, Haseeb AS, Celis JP. Tribo-surface characteristics of Aluminium-Boron Carbide and Aluminium-SiliconeCarbide composites worn under different contact pressures. Journal of Wear. 2006;261:634-41.

[161] Chapman TR, Niesz DE, Fox RT, Fawcett T. Wear resistant Aluminium Boron Carbide cermets for automotive brake applications. Journal of Wear. 1999;236(1-2):81-7.

[162] Jang H, Ko K, Kim SJ, Basch RH, Fash JW. The effect of metal fibers on the friction performance of automotive brake friction materials. Wear. 2004;256(3-4):406-14.

[163] WanNik WB. Ayoba AF, Syahrullailb S, Masjuki HH, Ahmad AF. The effect of boron friction modifier on the performance of brake pads [IJMME]. International Journal of Mechanical and Materials Engineering. 2012;7(1):31-5.

[164] Muzathik AM, Mohd Nizam YB, Prawoto Y, Ahmad MF, Wan Nik WB. Friction coefficients of boron mixed brake pads. General Applications and Processing of Materials: International Conference on Composites or Nano Engineering; 2011 Jul 24-30; Shanghai, China.

[165] Muzathik AM, Mohd Nizam YB, Ahmad MF, Wan Nik WS. The effect of boron on the performance of automotive brake. World J Eng. 2013;10(6):523-8.

[166] Muzathik AM, Mohd Nizam YB, Wan Nik WB. Effect of boron on friction and temperature characteristics of brake pad materials. Mater Sci. 2013;9(12):481-7.

[167] Cho MH, Ju J, Kim SJ, Jang H. Tribological properties of solid lubricants (graphite, $\mathrm{Sb} 2 \mathrm{~S} 3, \mathrm{MoS} 2$ ) for automotive brake friction materials. Wear. 2006;260(7-8):855-60.

[168] Österle W, Dmitriev Al. The role of solid lubricants for brake friction materials. Lubricants. 2016;4-5(1):1-22.

[169] Lin HY, Cheng HZ, Lee KJ, Wang CF, Liu YC, Wang YW. Effect of Carbonaceous Components on Tribological Properties of Copper-Free NAO Friction Material. Materials (Basel). 2020 Mar;13(5):1163.

[170] Blau PJ. Compositions Functions and Testing of Friction Brake Materials and Their Additives. Oak Ridge (TN): Oak Ridge National Laboratory; 2001. Report No.: ORNL/TM-2001/64. Sponsored by the Department of Energy. https://doi.org/10.2172/788356.

[171] Gilardi R, Alzati L, Thiam M, Brunel JF, Desplanques Y, Dufrenoy P, et al. Copper Substitution and Noise Reduction in Brake Pads: Graphite Type Selection. Materials (Basel). 2012;5(11):2258-69.

[172] Goudier M, Berthier Y, Jacquemard P, Roussenau B, Bonnamy S, Estrade-Szwarckopf $\mathrm{H}$. Mass spectrometry during $\mathrm{C} / \mathrm{C}$ composite friction: carbon oxidation associated with high friction coefficient and high wear rate. Wear. 2004;256(11-12):1082-7.

[173] Kasem H, Bonnamy S, Berthier Y, Dufrenoy P, Jacquemard P. Tribological, physicochemical and thermal study of the abrupt friction transition during $\mathrm{C} / \mathrm{C}$ composite friction. Wear. 2009;267(58):846-52.
[174] Stadler Z, Krnel K, Kosmac T. Friction and wear of sintered metallic brake linings on a C/C-SiC composite brake disc. Wear. 2008;265(3-4):278-85.

[175] Li X, Gao Y, Xing J, Wang Y, Fang L. Wear reduction mechanism of graphite and MoS2 in epoxy composites. Wear. 2004;257(34):279-83.

[176] Pan G, Guo Q, Ding J, Zhang W, Wang X. Tribological behaviors of graphite/epoxy two phase composite coatings. Tribol Int. 2010;43(8):1318-25.

[177] Cho KH, Jang H, Hong YS, Kim SJ, Basch RH, Fash JW. Fash. The size effect of zircon particles on the friction characteristics of brake lining materials. Wear. 2008;264(3-4):291-7.

[178] Chen B, Bi Q, Yang J, Xia Y, Hao J. Tribological properties of solid lubricants (graphite, h-BN) for Cu-based P/M friction composites. Tribol Int. 2008;41(12):1145-52.

[179] Su L, Gao F, Han X, Fu R, Zhang E. Tribological behavior of coppergraphite powder third body on copper-based friction materials. Tribol Lett. 2015;60(2):30.

[180] Ram-Prabhu T. Effects of solid lubricants, load, and sliding speed on the tribological behavior of silica reinforced composites using design of experiments. Mater Des. 2015;77:149-60.

[181] Yuan J, Zeng J, Duan Z, Pei W, Chen H. Effect of large size graphite on dry friction and wear characteristics of copper-based brake friction lining materials. IOP Conf. Series: Materials Science and Engineering. 2018;397:012054. https://doi.org/10.1088/1757899X/397/1/012054.

[182] Leonardia M, Alemani M, Straffelini G, Gialanella S. A pinon-disc study on the dry sliding behavior of a Cu-free friction material containing different types of natural graphite. Wear. 2020;442-443:203157.

[183] Kolluri DK, Boidin X, Desplanques Y, Degallaix G, Ghosh AK, Kumar M, et al. Effect of Natural Graphite Particle size in friction materials on thermallocalisation phenomenon during stop-braking. Wear. 2010;268(11-12):1472-82.

[184] Inada K, Aki M, Yamamoto Y. Relationship between powder properties of titanate compounds and brake performace. SAE paper 2005-01-3925, 2005.

[185] Radhakrishnan C, Yokeswaran P, Vengadeshprasadh M, Vishnuhasan A, Vimalraj T, Velusamy M. Design and analysis of disc brake with titanium alloy. International Journal of Innovative Science. Engineering \& Technology. 2015;2(5):1044-50.

[186] Kim YC, Cho MH, Kim SJ, Jang H. The effect of phenolic resin, potassium titanate, and CNSL on the tribological properties of brake friction materials. Wear. 2008;264(3-4):204-10.

[187] Kim SJ, Cho MH, Lim DS, Jang H. Synergistic effects of aramid pulp and potassium titanate whiskers in the automotive friction material. Wear. 2001;251(1-12):1484-91.

[188] Kazuhisa M, Buckley DH. Correlation of tensile and shear strengths of metals with their friction properties. ASLE Trans. 1984;27(1):15-23.

[189] Ho SC, Cu Lin JH. Effect of fiber addition on mechanical and tribological properties of a copper/phenolic-based friction material. Wear. 2005;258(5-6):861-9.

[190] Sugözü I. Investigation of Using Brass Particles in Automotive Brake Linings. Int J Innov Res Sci Eng Technol. 2016;5(12):24-9.

[191] Eddoumy F, Kasem H, Dufrenoy P, Celis JP, Desplanques Y. Friction and wear studies on the temperature dependence of brake-pad materials containing brass. MATEC Web of Conferences. 2013;7:56-58. https://doi.org/10.1051/matecconf/2013 0701020 . 
[192] Kharrat MB, Cristol AL, Elleuch R, Desplanques Y. Brass in brake linings: key considerations for its replacement. Proc Inst Mech Eng, Part J J Eng Tribol. 2015;208-210:1-8.

[193] Kumar M, Bijwe J. Optimized selection of metallic fillers for best combination of performance properties of friction materials: a comprehensive study. Wear. 2013;303(1-2):569-83.

[194] Sellami A, Kchaou M, Kus R, Fajoui J, Elleuch R, Jacquemin F. Impact of brass contents on thermal, friction and wear properties of brake linings composites. Mech Ind. 2018;19(1):105.

[195] Morshed MM, Haseeb AS. Physical and chemical characteristics of commercially available brake shoe lining materials: a comparative study. J Mater Process Technol. 2004;155-156:1422-7.

[196] Tarasiuk W, Szymczak T, Borawski A. Investigation of surface after erosion using optical profilometry technique. Metrol Meas Syst. 2020;27(2):265-73.

[197] Bijwe J, Kumar M. Optimization of steel wool contents in nonasbestos organic (NAO) friction composites for best combination of thermal conductivity and tribo-performance. Wear. 2007;263(7-12):1243-8.

[198] Borawski A, Borawska E, Obidziński S. Research on possibility of using plant-derived materials in friction elements of slowrunning agricultural machinery braking systems, Proceedings of Engineering for Rural Development: 19th International Scientific Conference; 2020 May 20-22; Jelgava, Latvia. Latvia University of Life Sciences and Technologies; 2020. p. 541-548.

[199] Vijay R, Singaravelu DL, Jayaganthan R. Development and characterization of stainless steel fiber-based copper-free brake liner formulation: A positive solution for steel fiber replacement. Friction. 2020;8(2):396-420.
[200] Rampin I, Zanon M, Etxeberria JM, DiLoreto A, Martinez AM. Development of copper-free low steel brake pads for passenger cars. PM 2014: 3rd World Congress on Powder Metallurgy and Particulate Materials; 2014 May 18-22; Orlando, USA.

[201] Aditya B, Ashok S. New generation iron powder friction material for brake pad applications. EuroBrake 2016: Milano Congressi; 2016 Jun 13-15; Milano, Italy.

[202] Asif M, Chandra K, Misra PS. Development of iron based brake friction material by hot powder preform forging technique used for medium to heavy duty applications. J Miner Mater Charact Eng. 2011;10(3):231-44.

[203] Lazarev GE. Evaluation of wear resistance of friction materials. Chem Petrol Eng. 1971;7(10):903-5.

[204] Jetley S. Martempering to improve wear properties of aircraft brake steel rotors. J Inf Technol. 2007;23(2):1-10.

[205] Keskin A. Investigation of using natural zeolite in brake pad. Sci Res Essays. 2011;6(23):4893-904.

[206] Chau JL, Lee CC, Yang CC, Shih HH. Zeolite-coated steel fibers for friction materials applications. Proceedings of the Institution of Mechanical Engineers, Part L: Journal of Materials: Design and Applications Institution of Mechanical Engineers. 2016;230(1):3542. https://doi.org/10.1177/1464420714542053.

[207] Borawski A. Research in impact of cargo vehicle load weight on braking system element heating process in single emergency stopping. Proceedings of Engineering for Rural Development: 19th International Scientific Conference; 2020 May 20-22; Jelgava, Latvia. Latvia University of Life Sciences and Technologies; 2020. p. 578-584.

[208] Eriksson M, Bergman F, Jacobson S. On the nature of tribological contact in automotive brakes. Wear. 2002;252(1-2):26-36. 